Revista Portuguesa de História

t. XXXI, Vol. I(1996)

\title{
GERALDO PERES, CÓNEGO DA SÉ DE COIMBRA NO SÉCULO XIV
}

\author{
MARIA DO ROSÁRIO BARBOSA MORUJÃO \\ (Universidade de Coimbra)
}

Estamos em 1348. No dia 28 de Dezembro, no coro da Sé de Coimbra, tem lugar uma cerimónia: um jovem recebe a prebenda deixada vaga pelo falecimento do cónego Fernando da Guarda (vitimado talvez pela Peste Negra, que então grassava); de acordo com o costume, o recém-nomeado cónego é conduzido aos lugares no coro e no capítulo que passam a ser seus, e investido na prebenda "per denarios et per panem in celario et vinum in apotheca ipsius capituli"'.

É este o primeiro acto que refere Geraldo Peres, assim empossado como cónego da prestigiada catedral conimbricense. De 1348 até 1401 , mais de cem documentos ${ }^{2}$ guardaram a memória deste $\mathbf{n}^{\circ} 58$.

'Arquivo da Universidade de Coimbra (=AUC), Móvel (=Móv.) 1, Gaveta (=G.) 2,

No Arquivo da Universidade de Coimbra conservam-se os pergaminhos directamente respeitantes a Geraldo Peres, num núcleo não muito bem conservado que parece ter constituido como que um arquivo pessoal, guardado pelo próprio cónego, e que o destino manteve coeso até ao presente. Completámos essas informações com notícias encontradas nos fundos da Sé de Coimbra da Torre do Tombo (=TT), que nos apresentam essencialmente dados sobre a sua vida capitular. Dois documentos pertencem 
homem, e ao dar-nos uma imagem do indivíduo que ele foi fornecem também dados sobre a instituição a que pertenceu e a sociedade em que se integrava. É nosso intuito, através do estudo da sua biografia, atingir o colectivo em que se enquadrava e de que era, de algum modo, representante ${ }^{3}$ : este cónego pode ser considerado como um exemplo, um caso ilustrativo do que seriam os membros dos cabidos catedralicios, uma das elites urbanas medievais, verdadeira "aristocracia" do clero secular ${ }^{4}$ que está ainda praticamente por estudar em Portugal'.

A escolha de Geraldo Peres como figura a analisar não resulta, naturalmente, de um acaso. A nossa atenção foi atraída pela variedade e riqueza dos testemunhos a seu respeito. Além de simples referências ao seu nome (por ter assistido a um qualquer acto jurídico ou participado em reuniões do cabido) e de documentos em que tem uma actuação "oficial", possuímos cartas de quitação e de doação em seu favor, informações sobre a sua família e património, o testamento que lavrou ao sentir aproximar-se a

ao arquivo pessoal da família Rocha Madahil, em Ílhavo, e foram publicados no Milenário de Aveiro. Colectânea de documentos históricos, I: 959-1516. org.. leitura e revisão de António Gomes da Rocha Madahil, Aveiro, 1959.

${ }^{3}$ Sobre a reabilitação da biografia como género historiográfico nos últimos tempos e a consciência crescente da sua importância para o conhecimento global do passado. $I$ a introdução que faz Bernard Guenée à sua obra Entre l'Église et l'État. Quatre vies de prélats français à la fin du Moyen Age, Paris, 1987, e Problèmes et méthodes de la biographie. Actes du Colloque Sorbonne. 3-4 Mai 1985, Paris, 1985.

“ Assim chamou Gama Barros aos bispos e aos seus cabidos, bem como aos membros das colegiadas (História da administração pública em Portugal, 2- ed., I I, Lisboa, sd, p. 76).

'Ao contrário, por exemplo, do que se tem feito em França, onde os estudos prosopográficos sobre os clérigos dos cabidos catedralícios têm permitido conclusões bem interessantes (v. Hélène Millet, L'ordinateur et la biographie ou la recherche du singulier, in Problèmes et méthodes de la biographie...,p. 115-127). A falta de trabalhos neste domínio limita necessariamente as possibilidades do estudo que nos propomos realizar: é quase impossível inserir a figura de Geraldo Peres num contexto que apenas se conhece em linhas muito vagas e gerais. 
morte. São dados que nos revelam o homem, ao longo de mais de cinquenta anos, e nos permitem conhecer múltiplas facetas da sua vida: a carreira eclesiástica; os estudos; as relações familiares e humanas; o seu património.

\section{A carreira eclesiástica}

Foi em 1348, como vimos, que Geraldo Peres deu entrada no cabido de Coimbra. A essa concessão não era sem dúvida alheio o facto de ser sobrinho do então bispo da diocese, D. Jorge. O nepotismo no acesso aos lugares eclesiásticos era prática comum, perfeitamente admitida pela mentalidade da época ${ }^{6}$.

A confirmação apostólica da sua nomeação como cónego não tardou muito; foi pedida a 4 de Outubro de $1349^{\prime}$, e obtida por mão do papa Clemente VI. A anata por ela devida (cinquenta libras) parece ter sido paga bastante mais tarde. De facto, em 1367 Geraldo Peres entrega essa quantia em escudos e dobras de ouro ao socoIhedor dos bens da câmara papal no bispado de Coimbra, com a condição, porém, de o dinheiro lhe ser devolvido caso se verificasse que o pagamento fora efectuado pelo antigo prebendeiro do cabido ${ }^{8}$.

\footnotetext{
'Veja-se o que diz a este respeito A. H. Oliveira Marques, Portugal na crise dos séculos XIV e XV, vol. IV da Nova História de Portugal, dir. Joel Serrão e A. H. Oliveira Marques, Lisboa. 1986, p. 229-230. Sobre o caso concreto do cabido conimbricense, diversos exemplos sucedidos com membros de familias francesas estão patentes em Pierre David, François du Midi dans les évêchés portugais (1279-1390), sep. «Bulletin des Études Portugaises», Lisboa, 1944. A mesma situação verifica relativamente ao cabido eborense Maria Angela Beirante, Évora na Idade Média, Lisboa, 1995, p. 512-513.

'Monumenta Portugaliae Vaticana, vol. I: Súplicas dos pontificados de Clemente VI, Inocêncio VI e Urbano V. publ. com introd. e notas por António Domingues de Sousa Costa, Roma-Porto, 1968, doc. $\mathbf{n}^{\circ}$ 314. p. 167.

${ }^{8}$ AUC. Móv. 1, G.3, no 99, de 1367 Setembro, 27, Coimbra (Sé).
} 
Em 1352, o cónego recebe novo benefício: o priorado da paróquia de S. Miguel de Aveiro', de que foi titular absentista, limitando-se a auferir rendimentos sem desempenhar funções de prior $^{10}$. Estas estariam a cargo de um subdiácono, enquanto Geraldo Peres frequentasse o Estudo Geral ". Findos os estudos, a situação de absentismo parece ter-se mantido, como indiciam a ausência de referências documentais à sua presença em Aveiro e o arrendamento da paróquia a que procede em $1396^{12}$, e que nos permite avaliar da riqueza que este benefício lhe trazia, pois o contrato prevê o pagamento anual de seis mil libras e de uma carga de "boom pescado seco rrecebondo".

Cónego da Sé, Geraldo Peres tinha obrigações a cumprir ${ }^{13}$, principalmente a participação nas cerimónias litúrgicas e nas

\footnotetext{
'Milenário de Aveiro..., doc. $\mathrm{n}^{\circ}$ 67, p. 128-129. A 8 de Julho, o bispo D. Jorge manda confirmar Geraldo Peres como prior daquela igreja apresentado pelo rei, e empossá-lo no cargo através do seu procurador Gonçalo Martins, prior de Macieira. A 10 do mesmo mês dá-se efectivamente a tomada de posse. Sobre a igreja de S. Miguel e a sua importância como sede da única freguesia aveirense até ao século XVI, v. Maria João V. B. Marques da Silva, Aveiro medieval, Aveiro, 1991.

${ }^{10} \mathrm{O}$ absentismo dos párocos era um fenómeno muito vulgar na Idade Média, com consequências gravosas para as igrejas. José Marques, na obra $A$ arquidiocese de Braga no século $X V$, Lisboa, 1988, p. 1129-1137, refere-o como um dos principais males que afectava o clero bracarense e estuda as medidas anti-absentistas tomadas pelo arcebispo D. Fernando da Guerra no século XV. Este e muitos outros aspectos da vida eclesiástica medieval foram estudados por Isaías da Rosa Pereira, $A$ vida do clero e o ensino da doutrina cristã, sep. «Lusitania Sacra», t. 10, Lisboa, 1978. Vários exemplos de absentismo dos párocos na região do Baixo Mondego encontram-se em Maria Helena da Cruz Coelho, O Baixo Mondego nos finais da Idade Média (Estudo de história rural), $2^{\mathrm{a}}$ ed., Lisboa, 1989, vol. I, p. 680-682.

"D. Jorge, por carta de 1352 Agosto, 10, Nogueira (copiada em pública-forma de 1363 Março, 24, Coimbra - AUC, Cofre, Colecção de pergaminhos extravagantes = Col. pergs. extr.), autoriza Geraldo Peres a nomear um subdiácono para o substituir no priorado enquanto estivesse a estudar.

Milenário de Aveiro..., doe. $\mathrm{n}^{\circ} \quad 79$, p. 152-153.

${ }^{13}$ As obrigações dos cónegos da arquidiocese de Braga, que nos podem servir de referência, encontram-se resumidas em José Marques, o. c., p. 342. V. também Dicionário de História de Portugal, dir. Joel Serrão, Porto, sd., s.v. "Cabido" (da autoria de Avelino de Jesus da Costa) e "Cónego" (de A. Domingues de Sousa Costa).
} 
reuniões do cabido, que se realizavam geralmente no claustro da Sé. Está documentada a sua presença em trinta e uma assembleias capitulares, entre 1362 e $1397^{14}$, como mostra o quadro $n^{\circ} 1$.

A partir de Outubro de 1372, encontramo-lo como vigário-geral do bispo de Coimbra. Era um cargo importante, pois era ele quem representava o prelado nos assuntos de administração da diocese e quem em seu nome presidia à audiência, ouvia e julgava os feitos trazidos perante a justiça episcopal. Geraldo Peres exerceu tais funções entre 1372 e $1384^{15}$, durante o governo de D. Pedro Tenório (1371-1378), a vacância que se seguiu à sua transferência para Toledo e o episcopado ${ }^{16}$ de D. João Cabeça-de-Vaca

${ }^{14}$ A 2 de Maio de 1398, Geraldo Peres avisa que não pode comparecer à reunião, mas que concorda com o que for decidido pelos seus colegas de cabido relativamente a um escambo (TT, Sé C ${ }^{\mathrm{a}}, 2^{\mathrm{a}}$ inc, M. 64, n⿳2 2354).

${ }^{15}$ A 14 de Julho de 1372 ainda o cónego Fernão Gil exercia essas funções (TT, Sé $C^{a}, 2^{a}$ inc., M. 10, $n^{\circ}$ 464), que em Outubro já cabiam a Geraldo Peres. Quanto à data em que deixou de desempenhar o cargo, a última referência certa é de Maio de 1384. Sabemos que o seu "mandato" chegou ao fim enquanto decorria junto do arcebispo de Braga a apelação de uma sentença que pronunciara sobre dízimos que tanto o cabido conimbricense como o mosteiro de $S$. Pedro de Rates reclamavam; substituiu-o então o cónego Vicente Anes, estando a Sé vacante (TT, Sé Ca , 2- inc, M. 5, no 284, de 1386 Junho, 6, data da sentença do arcebispo). Ainda sem bispo eleito, era vigário da diocese em Julho e Outubro de 1385 o cónego Martim Domingues (TT, Sé Ca, $2^{\mathrm{a}}$ inc, M. 7, $\mathrm{n}^{\circ}$ 363 e M. 3, $n^{\circ} 130$, respectivamente). Note-se que se estava em plena crise dinástica, e os tumultos que então se viviam tinham certamente reflexo no funcionamento do cabido catedralicio. As informações sobre a actuação de Geraldo Peres como vigário-geral encontram-se condensadas no quadro $\mathrm{n}^{\mathrm{n}} 2$, para o qual remetemos.

${ }^{16}$ Há muitas dúvidas acerca dos bispos da diocese coimbrã no último quartel do século XIV, época especialmente perturbada tanto no plano interno, com as guerras fernandinas, como a nível externo, devido ao Cisma, iniciado em 1378. As notícias a respeito de D. João Cabeça-de-Vaca cessam em 1382 (segundo Pierre David, "Coimbra",

Dictionnaire $d$ 'histoire et de géographie ecclésiastiques, t. XII, Paris, 1953, e Miguel de Oliveira, História eclesiástica de Portugal, 4" ed., Lisboa, 1968, p. 127). Em 1383, Clemente VII transfere para Coimbra Fr. Ângelo, bispo de Pesaro, mas a nomeação não tem efeito. Em 1384, sabe-se que está refugiado em Castela um bispo de Coimbra, de obediência clementina, chamado João, provavelmente o Cabeça-de-Vaca. Na documentação por nós analisada, em Maio de 1384 o bispo é ainda D. João. Depois terá havido um período de dois anos sem prelado na diocese e finalmente, em 1386, a eleição de D. Martinho; segundo Miguel de Oliveira, chamava-se Martinho Afonso de Miranda, 
(1378-1384). Mais tarde, em 1398 e 1399, estando vaga a cadeira episcopal, ocupa de novo este cargo, por decisão capitular e de forma intermitente ${ }^{17}$.

Conhecemos vinte e cinco testemunhos da actuação nestas funções do "honrrado barom e sages Girai Perez" ${ }^{18}$ em assuntos que, maioritariamente, envolviam interesses do cabido (como o pagamento de dízimos e outros direitos eclesiásticos e a exploração do património) ou a autorização da cópia em pública-forma de documentos vários, geralmente cláusulas testamentárias. O vigário apunha a sua assinatura nos documentos que consignavam por escrito o decidido, e que eram autenticados com o selo da audiência da cúria episcopal. Quando estava ausente, podia ser substituído por um outro clérigo capitular - nas duas ocasiões em que tal sucedeu com Geraldo Peres, presidiu à audiência, "tenente vezes" do vigário, o prior de Santiago de Coimbra.

Cónego prebendado da Sé, prior de Aveiro, Geraldo Peres recebeu ainda um terceiro benefício: em 1380, foi eleito raçoeiro da colegiada de S. Pedro de Coimbra ${ }^{19}$. O documento que consigna esta eleição merece que nos detenhamos sobre ele, pelo que revela sobre a vida de Trezentos, ao justificar uma ausência à reunião do

e governou até 1398; de acordo com Pierre David, terá havido dois bispos com o mesmo nome próprio, o primeiro entre 1386 e 1395, o segundo. D. Martinho Pires, de 1396 a 1398.

${ }^{17}$ Como mostra o quadro $\mathbf{n}^{\circ}$ 2: Geraldo Peres é vigário-geral em conjunto com o cónego Paio Martins em Novembro de 1398. Desempenha sozinho o cargo em Janeiro. Abril e Junho de 1399, mas em Maio, Julho e Agosto desse mesmo ano exerce tais funções o mesmo Paio Martins (respectivamente TT, Sé $C^{\mathrm{a}}, 2^{\mathrm{a}}$ inc, M. 59, n $^{\mathrm{o}} 222$ e 2223 e M. 57, $n^{\circ}$ 2128). A Sé encontrava-se então vaga porque o bispo $D$. Martinho tinha sido transferido para a arquidiocese de Braga, como nos informa TT, Sé $C^{\mathrm{a}}, 2^{\mathrm{a}}$ inc., M. 59, $\mathbf{n}^{\circ} 2220$.

${ }^{18}$ Assim o refere TT. Sé C ${ }^{\mathrm{a}}, 2^{\mathrm{a}}$ inc., M. 1, $\mathbf{n}^{\mathbf{0}} 37$.

${ }^{19}$ Ia ocupar uma ração vaga por morte de Antoninho Esteves (AUC, Móv. 1, G.4, no 136, de 1380 Junho, 27, Coimbra). 
cabido e descrever pormenorizadamente o cerimonial da posse da ração.

O prior, o chantre e dois raçoeiros de S. Pedro estavam reunidos no coro da igreja para proceder à eleição, que, de acordo com os estatutos, se devia efectuar na presença de todos os beneficiados. Faltava, porém, Vicente Domingues; foi chamá-lo o porteiro da audiência dos vigários de Coimbra, que ao regressar "deu en ffe" que fora a sua casa e o achara de cama, "agravado de door"; explicara-lhe ao que vinha, e o raçoeiro respondera "que el jazia ora com sua sazom e que nom podia alii viir nem outrosi jazia en tempo pera constituir procurador pera elo". Justificada a falta, os presentes procederam à eleição de Geraldo Peres, de seguida investido na ração "per apposicom do (...) barrete que lhi logo presencialmente o dicto priol pos na cabeça". Depois, o prior e os raçoeiros receberam-no "en seu irmãao e companheiro per obsculo que lhi logo derom beijando o cada huum na façe singularmente" e fizeram-no tomar posse real e corporal da ração "per tradicom de pam vinho dinheiros livros canpaas e outros ornamentos ecclesiasticos (...) e per asiignamento de scalo no dicto coro e logar no dicto cabidoo". Finalmente, o novo raçoeiro jurou nas mãos do prior obedecer-lhe, cumprir os estatutos e constituições da igreja e não revelar os segredos da colegiada ${ }^{20}$.

${ }^{20}$ No cumprimento dos seus deveres como raçoeiro da colegiada, encontramo-lo numa reunião do cabido de S. Pedro em 1383 (AUC, Móv.l, G.5, no 146; o mês e o dia estão ilegíveis, mas um sumário do século XVIII no verso indica o dia 24 de Janeiro; também o patronímico de Geraldo Peres se lê muito mal, por se encontrar junto a uma parte roída do pergaminho). 


\section{Os estudos}

Esta é a faceta de Geraldo Peres sobre a qual menos informações possuímos.

Sabemos que em 1352, um mês depois de receber o priorado de Aveiro, D. Jorge o autorizou a estudar Direito no Estudo Geral durante sete anos ${ }^{21}$. Em 1363, o cónego pede ao vigário-geral da diocese-ao tempo Antão Martins-o consentimento para lavrar uma pública-forma dessa autorização, por medo de a perder. É curioso tal cuidado, onze anos volvidos; faz-nos pensar que Geraldo seria estudante em 1363, e precisava do documento para provar que estava autorizado a frequentar a Universidade.

Confirma esta hipótese uma referência ao cónego no Livro Verde da Universidade, de 7 de Agosto de $1368^{22}$, altura em que o Estudo Geral se encontrava em Coimbra. Na catedral da cidade, o procurador da Universidade, na presença de outros escolares do Estudo, pede a Geraldo Peres, prior de Aveiro, "como a comisairo que era e tente vezes do priol de Sam Jorge rector da dicta universsidade", e a Pero Domingues, mestre de Gramática, que façam cumprir o estatuto relativo à almotaçaria aprovado pela Universidade mas que, por ainda não ter sido passado a escrito, sofria contestação por parte dos estudantes ${ }^{23}$. Geraldo Peres estava, pois,

${ }^{21}$ V. doc. citado na nota 11. Este tipo de carta de autorização e o seu clausulado deviam ser usuais, já que o Regimento da chancelaria de Braga, actualizado por D. Fernando da Guerra em 1464, estipula a taxa e os emolumentos do escrivão a cobrar por uma carta de licença para clérigo frequentar os Estudos durante sete anos, dispensando-o de, entretanto, receber ordens maiores (José Marques, o. c, p. 1158).

${ }^{22}$ Livro Verde da Universidade de Coimbra, transcrição de Maria Teresa Nobre Veloso, Coimbra, 1992, doc. $\mathrm{n}^{\circ} 10$ (também publicado no Chartularium Universitatis Portugalensis, vol. I, Lisboa, 1966. doc. $\mathrm{n}^{\circ}$ 260).

${ }^{23}$ Este episódio é referido por Mário Brandão e M. Lopes de Almeida, A Universidade de Coimbra. Esboço da sua história, Coimbra, 1937, p. 98, obra em que se colhe grande 
a substituir um dos reitores, que na época, como se sabe, eram alunos e não professores; nesta data era, portanto, estudante, e ocupava lugar de relevo na comunidade universitária.

Sobre o final dos seus estudos, só podemos dizer que é pela primeira vez designado bacharel em Decretos em Julho de $1373^{24}$.

Os conhecimentos jurídicos foram-lhe certamente úteis ao longo da vida, quer para o exercício das funções de vigário, quer na própria gestão dos seus bens patrimoniais. Sabemos também que dava por vezes conselhos de direito - assim o atesta, reconhecido, um casal de Penela, que avalia as boas obras recebidas em quinhentas libras ${ }^{25}$.

\section{Relações familiares e humanas}

Dissemos já que o cónego Geraldo Peres era sobrinho do bispo D. Jorge. Prelado da diocese de Coimbra durante quase duas décadas, entre 1338 e 1357, nada se sabe porém a seu respeito, o que já admirava Pedro Álvares Nogueira, que no Livro das vidas dos bispos da Sé de Coimbra se limita a indicar a data do falecimento, 20 de Fevereiro de 1357, e o local da sepultura, na Sé, diante do altar de Nossa Senhora ${ }^{26}$.

Os documentos que analisámos não prestam mais informações sobre D. Jorge - apenas que protegeu o sobrinho, e que este

número de informações relativas à Universidade medieval. Sobre a permanência do Estudo em Coimbra por duas vezes no século XIV e a ambiência da cidade nesse tempo, v. Maria Helena da Cruz Coelho, Coimbra trecentista. A Cidade e o Estudo, sep. «Biblos», vol. 68(1992).

${ }^{24}$ A U C, Móv. 1,G.4, no 115.

${ }^{25}$ AUC, Móv.l, G.5, no 162, de 1391 Agosto, 1, Coimbra.

Pedro Alvares Nogueira, Livro das vidas dos bispos da Sé de Coimbra, lido, prefaciado e publ. por António G. da Rocha Madahil. Coimbra, 1942, p. 122. 
acarinhava a sua memória. Assim o revelam as últimas vontades expressas no seu testamento ${ }^{27}$, ao instituir aniversários e missas oficiadas por alma do tio e pela sua ${ }^{28}$.

Além do tio, conhecemos outros membros da sua família. Uma irmã, Margarida Peres, fora casada com Vasco Lourenço, almoxarife da Lousã de 1348 a 1355 e já falecido em Janeiro de 1365. Entre 1366 e 1371, a viúva viu-se a braços com a exigência do pagamento de mais de 500 libras de dívidas deixadas pelo marido ${ }^{29}$. Os sacadores das dívidas do rei penhoraram os seus bens e os do testamenteiro do marido, o escudeiro Pero Lourenço (provavelmente irmão do antigo almoxarife, também morador na Lousã). Ao lado da irmã esteve sempre o cónego, de forma discreta (arrematando algumas das propriedades postas em pregão através de pessoas da sua clientela ${ }^{30}$ ) ou mais visível (comparecendo junto das entidades competentes para provar o pagamento, trocando bens seus por outros na Lousã para lhos devolver e ela se poder "manteer

${ }^{27}$ Lavrado na própria casa de Geraldo Peres em 1399 Outubro, 31 (AUC, Móv.7, G.4, $\mathrm{n}^{\mathrm{0}}$ 43).

${ }^{28}$ Indica ainda que saíssem sobre o "muimento" de D. Jorge com cruz e água benta e rezassem a oração Deus qui inter apostolicos, prece do ofício dos defuntos.

${ }^{29}$ Os dados relativos às dívidas de Vasco Lourenço estão patentes no quadro $\mathbf{n}^{\mathbf{0}} \mathbf{3}$, onde sumariámos todos os documentos sobre este assunto, que podiam ser aproveitados para o estudo da forma como a oficialidade régia actuava para cobrar as suas dívidas, tema que de momento não nos interessa explorar. Veja-se de qualquer forma, para melhor compreensão do problema, o que diz Marcello Caetano, História do Direito Português. Fontes — Direito Público (1140-1495), 2 $2^{a}$ - ed., Lisboa, 1985, p. 395-399. Repare-se também que Vasco Lourenço, tendo sido almoxarife até 1355 , só oito anos volvidos recebeu a carta de quitação referente ao seu ofício, e que apenas em 1366 se inicia a cobrança das dívidas que entretanto se descobrira existirem - uma lentidão de processos que decerto se explica pelo "emaranhado da maneira de contabilizar ", como conclui Vitorino Magalhães Godinho em relação ao tempo de D. Manuel, a partir do estudo das cartas de quitação passadas por esse monarca (Finanças públicas e estrutura do Estado. in Dicionário de História de Portugal, vol. III).

${ }^{30}$ V. mais à frente o que dizemos acerca da forma como Geraldo Peres contornou as leis contra a amortização. 
em onrra come molher veuva que era".

Geraldo Peres tinha certamente mais irmãos, pois os documentos mencionam quatro sobrinhos. De um deles, Gonçalo Domingues, foi tutor; os pais deixaram-lhe em herança bens que o tio administrou e lhe entregou em 1380, estando ele já casado e morando em Mouronho ${ }^{31}$. Dois outros sobrinhos são referidos enquanto testemunhas de actos escritos: Álvaro, em $1396^{32}$, e Gonçalo Gonçalves, em $1397^{33}$. Uma sobrinha, de nome Constança, foi contemplada no testamento com um marco de prata "pera ajuda de casamento seu".

Geraldo Peres é um bom exemplo de como o clero medieval respeitava pouco a legislação canónica no tocante à lei do celibato $^{34}$. Sabemos que foi pai de três filhos, dois dos quais, Fernão e Margarida Peres, legitimou e se encontravam sob sua tutela em 1399-1400. Fernão testemunha a posse de vinhas do pai em $1397^{35}$, o que implicava ter no mínimo catorze anos de idade ${ }^{36}$. São estes

${ }^{31}$ AUC, Móv.1, G.4, ${ }^{\circ}$ 132, de 1380 Maio, 7, Coimbra. O sumário no verso atesta o grau de parentesco entre os dois. Eram seus pais Domingos de Arganil e Catarina André; seria ele irmão do cónego? Mouronho é uma freguesia do concelho de Tábua, situada não muito longe de Arganil.

Milenário de Aveiro, doc. $\mathrm{n}^{\circ}$ 79, p. 153.

AUC, Móv.l, G.6, no 177v. O patronímico Gonçalves permite-nos pensar que seria filho do já referido sobrinho Gonçalo Domingues, que, casado em 1380, podia perfeitamente ter um filho com idade para testemunhar em 1397.

${ }^{34}$ Vejam-se os dados apresentados por José Marques, o. $c$, p. 1004-1024, bem elucidativos sobre o estado do clero a este nível na arquidiocese de Braga em Quatrocentos, e que não era por certo muito diferente do que se passava no resto do país no século anterior. Relativamente a Évora, observa Maria Angela Beirante (o. c. p. 511-512), que, a avaliar pelas cartas de legitimações, a maior parte dos clérigos da Sé tinha filhos.

${ }^{35}$ A UC, Móv.l, G.6, $\mathbf{n}^{\circ}$ 177v.

${ }^{36}$ Era esta a idade mínima para os menores serem considerados aptos a prestar testemunho. V. sobre este assunto René Metz, L enfant dans le droit canonique médiéval Orientations de recherche, p. 74-80, in La femme et l'enfant dans le droit canonique médiéval, Variorum Reprints, Londres, 1985. V. também o que diz um dos documentos 
dois filhos as primeiras pessoas referidas no testamento do cónego e que recebem o grosso dos bens. A Margarida, já casada então, deixa também uma "taça dourada com huum esmalte de colheres meudas de marco e meo". São ainda ambos referidos numa carta de Janeiro de 1400, pela qual dá "em casamento" à filha e ao genro (Lourenço Gonçalves, mercador, morador em Avô) vinhas na Lousã, aproveitando a ocasião para fazer partilhas com o filho ${ }^{37}$. Desconhece-se o nome da sua mãe, a que o testamento não faz alusão - talvez fosse Maria Gomes, natural de Coimbra e aí moradora, várias vezes referida nos documentos de Geraldo Peres próximos de 1370 como sua servidora, chaveira ou manceba ${ }^{38}$.

$\mathrm{O}$ terceiro filho chamava-se Afonso, e recebeu pelo testamento - único documento que a ele alude - um pomar com vinha e olival em Vialonga, no termo de Coimbra. Sua mãe, Margarida, vivia então com o coudel Martim Anes; a ela foi legado um marco de prata, "por serviço que me fez".

Existe ainda um conjunto de pessoas relacionadas com o cónego por laços a que podemos chamar, genericamente, de dependência ou clientelismo ${ }^{39}$. A documentação designa-os quase sempre como "homens de Geraldo Peres", e surgem na maioria dos casos como testemunhas de actos jurídicos (veja-se o quadro $n^{\circ} 4$ ). Salientem-

analisados neste estudo acerca do testemunho de uma jovem, chamada a depor numa questão que envolvia a avó, sua tutora, e que teve de provar ter mais de catorze e menos que os vinte e cinco anos que marcavam a maioridade (AUC, Móv. 1, G.6, $\mathbf{n}^{\circ}$ 172).

${ }^{37}$ AUC, Móv.7, G.4, no 44, de 10 de Janeiro de 1400, Coimbra (casa de Geraldo Peres).

${ }^{38}$ V. as referências a seu respeito no quadro $n^{0} 4$.

${ }^{39}$ Destes laços que se estabeleciam entre pessoas de estratos sociais e poderes diferentes nos fala Maria Angela Beirante, Os diferentes tipos de solidariedade na cidade medieval. $O$ exemplo de Évora, in Arqueologia do Estado. $l^{\text {ss }}$ Jornadas sobre formas de organização e exercício dos poderes na Europa do Sul, séculos XIII-XVIII, vol. I, Lisboa, 1988, p. 48-51. 
-se três deles que trabalhavam as herdades do clérigo na Lousã, cavando as vinhas ou lavrando a terra com o auxílio de bois, um outro que era azemel, e um bacharel, designado como seu "criado".

Nesta teia de relações não podemos deixar de referir ainda os homens em quem o cónego depositou a confiança necessária para os nomear procuradores. Conhecemos quatro, como evidencia o quadro $\mathrm{n}^{\circ} 5$, dois dos quais membros do clero, outro medidor do celeiro do cabido da Sé; em seu nome tomam posse de bens, ou comparecem em demandas.

\section{O património}

Aos cónegos dos cabidos catedrais era permitido possuir e explorar propriedades. Como muitos outros, Geraldo Peres tinha bens próprios e trazia prazos da $\mathrm{Sé}^{40}$.

Em Fevereiro de 1363, foram-lhe entregues enquanto vivesse as casas em que habitara o falecido cónego Pero Vasques de Pedra Alçada, mantendo-se as condições do contrato anterior ${ }^{41}$; eram provavelmente essas as suas casas de morada, ao adro da Sé, onde foram lavrados nove dos documentos que lhe dizem respeito. Em data desconhecida, tornou-se também detentor de herdades e olivais pertencentes à catedral, e ainda da quinta do Beiçudo, também designada quinta de Traveira do Beiçudo (ambos os lugares pertencem à freguesia de Vila Seca, no concelho de Condeixa-

40 V. mapa $\mathbf{n}^{\circ} 1$.

${ }^{41}$ AUC, Móv.l, G.3, nº 86, de 1363 Fevereiro, 12, Coimbra; que condições eram essas, não o sabemos. Refira-se a propósito deste documento que nesse dia a reunião do cabido teve lugar não na Sé, como era habitual, mas na igreja de S. João de Almedina, porque as portas da catedral se encontravam embargadas e fechadas por "companhas" que lá dentro as guardavam por mandado do juiz da cidade Vasco Lourenço, não deixando os cónegos entrar. Ignoramos o que se terá passado. 
-a-Nova), e de casais em Bruscos (na mesma freguesia) que tinham sido de Vasco Afonso. De todos estes bens havia que pagar rendas ou pensões-e Geraldo Peres conservou bem guardadas diversas cartas de quitação que comprovavam ter pago o que devia aos prebendeiros da $\mathrm{Sé}^{42}$.

Quanto ao património que, pouco a pouco, o cónego foi adquirindo, era composto maioritariamente por bens concentrados em torno da Lousã. Nessa vila possuía pelo menos três casas ${ }^{43}$, um cortinhal onde existiam figueiras e que confrontava com uma dessas casas ${ }^{44}$, e parte de um outro cortinhal com chão e árvores ${ }^{45}$. Também tinha um forno, que provia de forneiros, cujas soldadas $\operatorname{pagava}^{46}$.

Nos arredores da Lousã, sucediam-se as propriedades rústicas, de que conhecemos um arrolamento feito em 1397, quando Geraldo Peres recuperou a sua posse após o senhor da vila, Gonçalo Mendes de Vasconcelos, lhas ter confiscado ${ }^{47}$. Nessa lista ${ }^{48}$ contam-se vinte e uma vinhas (duas das quais labruscas e outra

${ }^{42}$ V. quadro $\mathrm{n}^{0} 6$. Note-se que essas cartas mencionam o pagamento de outras dívidas do cónego, provenientes da compra de panos de cor e de empréstimos contraídos. E através destes documentos que conhecemos os prazos que trazia.

${ }^{43}$ Duas compradas por dependentes seus (v. quadro $\mathbf{n}^{\circ} 8$ ), a terceira doada juntamente com outros bens em 1379 (v. quadro $n^{0} 7$ ).

${ }^{4}$ V. quadro $n^{\circ} 7$.

${ }^{45}$ Adquirida por 20 soldos (v. quadro $\mathbf{n}^{0} 7$ ).

${ }^{46}$ V. de novo o quadro $n^{\circ} 7$.

${ }^{47}$ AUC, Móv.l, G.6, no 174, de 1397 Abril, 27, Urzidel. Ignoramos a causa desta confiscação. Quanto a Gonçalo Mendes de Vasconcelos, era tio de D. Leonor Teles e fora fronteiro-mor de Elvas e Lisboa e alcaide de Coimbra entre 1373 e 1385 . Em 1378, D. Fernando fez-lhe doação em préstamo das rendas e direitos da Lousã, doação essa que viria a ser confirmada em 1382 e de novo por D. João I, em 1384. Em 1389, a vila e termo foram-lhe doados com toda a jurisdição e "mero e misto império". V. a seu respeito Maria do Rosário Castiço de Campos, Lousã (1376-1428). Elementos para a sua história, Lousã, 1987, p. 27-34 e Maria Helena da Cruz Coelho, O Baixo Mondego..., vol. I, p. 516 e 520 .

${ }^{48}$ V. quadro $n^{o} 9$, onde se discriminam esses bens. 
alvar $^{49}$ ) e um bacelo junto a um salgueiral, dez herdades, duas cortes e uma "relva" (terreno relvado?), e referem-se matos maninhos que também eram seus. Estes bens são indicados com precisão, mas quase sempre impossíveis de localizar porque os microtopónimos não chegaram até hoje. Sabemos, de qualquer maneira, que muitas dessas propriedades confrontavam entre si e se situavam sobretudo em torno do chamado "caminho coimbrão", na zona do Areal, a oeste da vila, na Papanata e na Gândara.

Em Coimbra e arredores, possuiu o cónego até 1371 um olival acima de Santa Eufémia (freguesia de Ribeira de Frades) e outro em Vila Mendiga ${ }^{50}$, e tornou-se senhor na década de 90 de uma vinha no Almegue (freguesia de Santa Clara), comprada por duas mil libras ${ }^{51}$, e de duas leiras de herdade, uma com olival e uma vinha, no Vale da Machada, e outra com vinha, no Gestal ${ }^{52}$. Tinha ainda o pomar com vinha e olival em Vialonga que legou ao filho Afonso e mais longe, em Cernache, um conjunto de bens não especificados ${ }^{53}$.

No tocante aos processos de formação deste património,

\footnotetext{
"Sobre estas castas de uvas medievais, v. Maria Helena da Cruz Coelho, $O$ Baixo Mondego..., vol. I, p. 164-165.

${ }^{\text {so }}$ Foram estes olivais os bens que trocou com Maria Gomes para permitir à irmã viver uma viuvez honrada, como já referimos.

${ }^{51}$ Não conhecemos o documento comprovativo da compra, mas o instrumento de posse passado em 1394 (AUC, Móv. 1, G.6, no 170) e a indicação do preço da transacção numa questão de 1395 (AUC, Móv.7, G.4, $n^{\circ}$ 42). Nessa altura, parece que Geraldo Peres ainda não pagara o valor da vinha, tendo "socrestadas" em seu poder as 2000 libras; Maria Vasques, devendo essa quantia ao prior de Cernache, acorda com este que Geraldo Peres lhe entregará directamente o dinheiro, ficando ambas as dívidas saldadas, como de facto sucede (AUC, Móv.7, G.4, $\mathrm{n}^{\circ}$ 42). Entretanto, a mulher jura diante do vigário-geral da diocese que nunca demandará a vinha do Almegue ao cónego (AUC, Móv. 1, G.6, no 172).

s2 Obtidas como pagamento de uma divida em 1397 Out. 16, Coimbra (AUC, Móv. 1, G.6, $\mathbf{n}^{\circ}$ 177). V. infra, nota 58.

${ }^{s 3}$ Doados em 1388 - v. quadro $n^{0} 7$.
} 
conhecemos uma compra (a da vinha no Almegue a que nos referimos), um escambo (a que também aludimos já, e que terá revertido em favor da irmã) e sete doações, patentes no quadro $n^{\circ} 7$ e que passamos a analisar.

Exceptuando a primeira, feita pela irmã, todas são efectuadas por pessoas estranhas à família que desejam agradecer ajuda e benesses. Nalguns casos não se tratava de verdadeiras dádivas, mas sim de compras camufladas efectuadas pelo cónego, num estratagema para contornar as leis contra a amortização que proibiam aos clérigos comprar bens de raiz, mas não recebê-los em doação. Já D. Dinis referia esta prática e a condenava em Julho de 1305: "os prellados da minha terra e ordees e casas rreligyosas conpram herdamentos e posysoees (...) encobertamente per alguuns homeens que esas vendas fazen fengidiças dezendo que as conpram pera sy. E conpranas en tall maneira que as dam depois aos ditos prellados e pessoas" ${ }^{54}$. A lei proibia que os tabeliães lavrassem cartas de venda sem os compradores jurarem que a transacção se fazia realmente para si, mas não era cumprida com rigor ${ }^{55}$.

Este processo de aquisição é perfeitamente evidente num caso protagonizado por um casal de foreiros do cónego, um sapateiro da Lousã e sua mulher que, em 1385, compraram um salgueiral com chão na Ribeira de Arouce por trinta libras ${ }^{56}$, e o doaram de seguida a Geraldo Peres. Sucedeu porém que os vendedores, ao verem que a sua terra tinha sido afinal adquirida para um eclesiás-

${ }^{54}$ Lei de D. Dinis de 1305 Julho, 30, Lisboa \{Ordenações del-rei D. Duare, ed. preparada por Martim de Albuquerque e Eduardo Borges Nunes, Lisboa, 1988, p. 204-205).

${ }^{55}$ Vários exemplos que comprovam como esta prática era comum são aduzidos por Maria Helena da Cruz Coelho, O Baixo Mondego..., vol. I, p. 443-444.

${ }^{56}$ AUC, Móv. 1, G.5, no 159. de 1385 Junho, 10, nº 151. 
tico, se sentiram enganados, e puseram uma demanda perante os juízes da vila ${ }^{57}$. As partes acabaram por chegar a acordo, alegadamente para escusar trabalhos, danos, perdas e custos: o sapateiro e a esposa deram oito alqueires de milho aos queixosos, entregues por Geraldo Peres, que permaneceu na posse do salgueiral. O mesmo casal efectuara já um outro negócio, provavelmente também uma "venda fengidiça": compraram um forno na Lousã e deram-no ao cónego invocando, como um dos motivos, o facto de morarem na sua herdade. Operações do mesmo género se adivinham em compras realizadas por dependentes de Geraldo Peres e incidindo sobre bens que, mais tarde, encontramos em seu poder - veja-se o quadro $n^{\circ} 4$. Recorde-se que foi através deste mesmo processo que o cónego conseguiu adquirir os bens penhorados pelas dívidas do cunhado: não podendo ser ele a arrematá-los, fê-lo através de gente da sua clientela.

Podemos daqui concluir que a compra de propriedades, apesar de expressamente vedada aos clérigos por sucessivas leis, constituiu o principal meio de obtenção do património de Geraldo Peres. Somando os valores das aquisições em seu nome com a que ele próprio fez, obtemos um total de duas mil novecentas e noventa libras, o que, mesmo tendo em conta a grande inflação da segunda metade do século XIV, não seria quantia de somenos.

Uma outra forma de obter bens de raiz frequentemente utilizada pelos eclesiásticos era o empréstimo: as dívidas podiam ser remidas através da entrega de propriedades e assim ajudavam a acrescentar o património dos religiosos ${ }^{58}$. O mesmo parece ter feito Geraldo

${ }^{57}$ AUC, Móv.l, G.7, $\mathbf{n}^{0} 180$ (1390 Dezembro, 17, Lousã) e G.5, $\mathbf{n}^{\circ} 160$ (só se lê o ano, 1390); os documentos não são iguais, mas referem os mesmos factos.

${ }^{58}$ Assim verifica na zona de Coimbra Maria Helena da Cruz Coelho, $O$ Baixo Mondego..., vol. I, p. 506-507. 
Peres, ficando na sequência do empréstimo de duas mil libras senhor de duas leiras de herdade ${ }^{59}$.

Proprietário de um conjunto de bens não despiciendo, Geraldo Peres explorou-o e fê-lo render. Tinha propriedades aforadas ${ }^{60}$, procedia ao encabeçamento de casais ${ }^{61}$, fazia vinhas mortas produzir $^{62}$, plantava videiras onde antes só havia um chão ${ }^{63}$. A vinicultura parece mesmo ser o seu principal interesse, o que condiz com as tendências gerais da época ${ }^{64}$.

Mas a falta de mão-de-obra agrícola, flagelo da segunda metade de Trezentos, provocada pelo decréscimo demográfico e pelo êxodo para os centros urbanos, afectou-o como aos demais possidentes. A promulgação da Lei das Sesmarias, em 1375, agravava a situação, ao pôr em causa a permanência das terras desaproveitadas nas mãos dos seus proprietários. Nos concelhos nomeavam-se vedores com a específica missão de verificar o estado das herdades e fazer cumprir o estipulado por $1 \mathrm{ei}^{65}$. Neste contexto se

s" Esta dívida foi contraída pela mesma mulher que fora proprietária da vinha do Almeguc. Em 1397, Geraldo Peres cita-a perante a justiça episcopal, por lhe ter emprestado duas mil libras que ela não restituira; é na sequência da sentença, que a condena a pagar dentro de um prazo curto e sob pena de excomunhão, que ela prefere "encampar" as duas leiras de herdade ao cónego (AUC, Móv.l, G.6, n 177).

${ }^{\circ}$ O mencionado sapateiro da Lousã trazia aforado um casal, $\mathrm{c}$ um carpinteiro tinha a ração de uma das vinhas mencionadas no rol de 1397.

${ }^{6}$ Assim se depreende da referência às cortes de Papanata como cabeça de casal, nesse mesmo rol.

${ }^{62}$ O olival da Machada, nos arredores de Coimbra, tinha uma vinha morta quando entrou na posse de Geraldo Peres (v. documentos referidos na nota 59); dois anos mais tarde, $o$ testamento refere a vinha do olival sem tal adjectivo, o que indica que estaria a produzir.

${ }^{63}$ O chão junto ao salgueiral que é alvo de demanda em 1390 (cf. notas 56 e 57) é descrito no rol de 1397 como um bacelo.

${ }^{4} V$. a este respeito as páginas que ao fomento da vinha dedica Maria Helena da Cruz Coelho, $O$ Baixo Mondego....

${ }^{65}$ Conhecemos um bom exemplo do que se passava a este nível em Coimbra. O juiz e os vereadores da cidade nomearam Vasco Martins e Estêvão de Abreu vedores das herdades e mancebos, para nessa qualidade percorrerem o concelho verificando o estado 
integra o mais interessante documento sobre Geraldo Peres, que o mostra a ele próprio, em Maio de 1379, quando era vigário da diocese, a trabalhar as suas terras ${ }^{66}$. Simples atestação feita a pedido do cónego para comprovar o seu interesse em manter as propriedades produtivas, escrita com má letra e num português deturpado, este instrumento notarial é um testemunho precioso da realidade trecentista, porque foge a fórmulas e estereótipos. Nele se narra como o tabelião da Lousã Geraldo Eanes, indo com seu filho pelo caminho coimbrão ver as propriedades que possuía nos arredores da vila, deparou com o vigário da Sé que, com quatro homens, trabalhava numa herdade. A descrição dos labores agrícolas evoca as iluminuras medievais sobre o tema: Geraldo Peres semeia o milho que traz numa saca, pegando nela com uma mão e com a outra lançando o cereal no solo, enquanto dois homens lavram com duas jugadas de bois e outros dois cavam. A cena seguinte passa-se numa vinha próxima, onde o vigário pega na enxada e "arenda" o terreno junto às cepas ${ }^{67}$, tal como os obreiros que o acompanham. Entre o tabelião e o clérigo trava-se um diálogo, reproduzido num raro discurso directo que nos faz chegar o eco de uma conversa de há seis séculos. "Deus hos ssalve todos", saúda o notário, recebendo por resposta: "He ssejades vos vindo".

das propriedades. Tendo dúvidas sobre se deviam tomar pera o bem do comum as que encontraram sem produzir, os dois vedores perguntaram ao rei como haviam de actuar, ao que D. Fernando respondeu que mandassem aos senhores que as lavrassem, semeassem e aproveitassem, se não cumprir-se-ia a ordenação. Tudo isto fez Estêvão de Abreu saber à abadessa de Celas em Setembro de 1376, ordenando-lhe que cultivasse os bens improdutivos do mosteiro (TT, Celas, M. 12, n- 19, publ. em Maria do Rosário Barbosa Morujão, Um mosteiro cisterciense feminino: Santa Maria de Celas (séculos XIII a XV), Porto, 1991, p. 221-223).

${ }^{6}$ AUC, Móv. 1, G.4, no 129, de 1379 Maio, 21, Lousã, que publicamos em apêndice.

${ }^{67}$ Este verbo é usado para descrever um dos cuidados de que as vinhas necessitavam, e que deve corresponder ao aplainar dos montes de terra resultantes da cava à volta das cepas (v. Maria Helena da Cruz Coelho, O Baixo Mondego..., vol. I, p. 163). 
Pergunta então o tabelião: "Que vos trouxe ora a esta terra? Gram tempo ha que vos aqui nom vim." Responde o vigário: "Trouxe me esto que vos veedes e mingua de sservidores que nom posso aver por meus dinheiros, bem louvado a Deus e a nos outros", conta que possui esta propriedade há muito mais de um ano, que colhe os seus frutos e novos e quer continuar a explorá-la, pelo que pede ao tabelião que lavre um ou mais instrumentos comprovativos do seu interesse por ela. Geraldo Eanes continua o seu caminho, e ao regressar, "a cabo dü a grande ora", vê o cónego e os seus homens trabalhando na vinha e comenta: "Gram trabalho e oge o vosso!" Responde Geraldo Peres: "Ja vo 1lo dixe outra vez e esso medes vos digo", pedindo-lhe novo instrumento que ateste o seu interesse pela vinha e por todas as outras propriedades da Lousã.

Este documento, notável pelos aspectos aludidos, é-o também por mostrar a crise agrária dos fins do século XIV tal como um homem a sentiu na pele, vivendo o problema da escassa e cara mão-de-obra para lavrar a terra e os riscos de perder os direitos sobre os seus bens devido ao estatuído na Lei das Sesmarias, esforçando-se por manter as terras produtivas. Por tudo o que nos revela da vida de então, parece-nos justificado o espaço que dedicámos à sua análise.

\section{O testamento ${ }^{68}$}

Geraldo Peres lavrou o seu testamento, já o dissemos, em 31

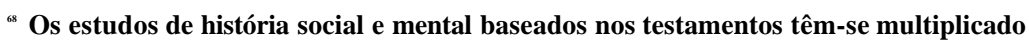
nas últimas décadas, no seguimento das obras já clássicas da historiografia francesa sobre a morte. Limitemo-nos a citar o trabalho de Maria Angela Beirante, Para a história da morte em Portugal (séc. XI-XIV), in Estudos de História de Portugal. Homenagem a A. H. de Oliveira Marques, vol. I: Séculos $X-X V$, Lisboa, 1982, p. 357-383, e a tese de mestrado de Hermínia Vilar, $A$ vivência da morte no Portugal medieval: a Estremadura portuguesa (1300 a 1500), Redondo, 1995. 
de Outubro de $1399^{\circ 9}$, em sua casa, onde chamou um tabelião de Coimbra que passasse a escrito as suas últimas vontades, revogando todos os anteriores testamentos que houvesse redigido.

Começa, como era de regra, por encomendar a sua alma a Deus, pedindo ajuda à Virgem Maria para que Cristo dela tenha mercê. Mas, curiosamente, pouco se detém em considerações de ordem religiosa; sem indicar sequer o local onde gostaria de ter a sua sepultura $^{70}$, entra directamente na disposição dos bens que possuía.

A divisão dos bens entre os seus familiares fomos aludindo ao longo do texto. Começa por dispor das herdades da Lousã, de que faz doação "antre os vivos valedoira" aos dois filhos; extinguindo-se a sua descendência directa e legítima, passarão a pertencer aos bacharéis da Sé de Coimbra, que deverão fazer com os seus rendimentos quarenta ou trinta aniversários por alma do bispo D. Jorge e pela sua. Já referimos o cerimonial a seguir ao saírem sobre o túmulo do tio; sobre o seu também se fará o mesmo, entoando três orações: Omnipotens sempiteme Deus, Deus qui nos patrem et matrem, Fidelium Deus ${ }^{71}$. Também para os bacharéis da catedral fica a vinha do Almegue, pedindo por ela doze missas oficiadas, uma em cada mês, por D. Jorge e por si. Deixa a Maria Afonso (que não sabemos quem é) e aos filhos o olival da Machada com a vinha do Gestal. A taça dourada fica para a filha Margarida, como dissemos, e faz legados ao filho Afonso e à sua mãe que

${ }^{69}$ AUC, Móv.7, G.4, no 43.

${ }^{70}$ Pelas disposições tomadas no tocante a missas e aniversários, ficamos a saber que o seu túmulo se situaria na Sé.

${ }^{71}$ Estas orações fazem parte do ofício de defuntos, sendo a segunda rezada por alma de pai e mãe, o que significa que Geraldo Peres não esqueceu nos aniversários que instituiu uma prece pelos seus progenitores. Queremos deixar aqui expresso o nosso agradecimento ao Sr. Professor Doutor José Antunes, que nos ajudou a identificar todas as orações indicadas. 
também já indicámos. Para ajudar ao seu casamento dá à sobrinha e a uma outra mulher "senhos" marcos de prata. Finalmente, fica para o clérigo Afonso Martins (provavelmente o bacharel seu criado mencionado entre a gente da sua clientela) o breviário que possuía.

Estas disposições testamentárias serão ligeiramente alteradas dois meses e meio mais tarde, pela carta que podemos talvez classificar de dote e de partilha ${ }^{12}$ através da qual entrega "em casamento" ao genro e à filha três das suas vinhas da Lousã e determina que os restantes vinhedos aí situados fiquem para o filho Fernão; os restantes bens da vila e do seu termo deverão ser repartidos igualmente entre os dois irmãos.

É este documento de 1400 o último que refere Geraldo Peres vivo. Um ano mais tarde, a 14 de Janeiro de $1401^{73}$, tinha já falecido. Nessa data é mostrado ao ouvidor de Coimbra um livro de notas do tabelião Vasco Martins Brandado onde se encontrava registado o testamento do cónego, e pede-se a cópia em pública-forma das cláusulas relativas aos legados à Sé. Questiona-se Fernão Peres sobre a sua intenção de aceitar a última vontade do pai, e face à resposta afirmativa manda-se proceder de acordo com o testamento ${ }^{74}$. No dia seguinte, os bacharéis da catedral tomam posse da vinha do Almegue, e o silêncio cai sobre Geraldo Peres, cessando as referências documentais a seu respeito. O Livro

${ }^{72}$ AUC, Móv.7, G.4, $\mathrm{n}^{\circ}$ 44, de 1400 Janeiro, 10, Coimbra (casa de Geraldo Peres). ${ }^{73}$ AUC, Móv.l,G.7, $\mathbf{n}^{\circ} 181$.

${ }^{74}$ Era este o procedimento correcto preconizado pela lei de D. Afonso IV de 22 de Maio de 1349, que obrigava a que os testamentos fossem apresentados às autoridades régias para lhes ser reconhecida validade (cf. Maria Helena da Cruz Coelho, Um testamento redigido em Coimbra no tempo da Peste Negra, sep. «Revista Portuguesa de História», t. 18, Coimbra, 1980, p. 315-317). 
das Kalendas ${ }^{75}$ não conservou a notícia da sua morte, nem dos aniversários e missas que instituiu.

O cónego morreu certamente nos finais de 1400. Fora membro do cabido catedralicio durante cinquenta e dois anos. Rondaria os setenta anos de idade - uma longa vida, num tempo em que a esperança média à nascença não ultrapassava a trintena ${ }^{76}$.

\section{Conclusão}

Percorremos a vida de Geraldo Peres. Procurámos deixar os documentos falar a seu respeito, limitando-nos quase a ordenar e condensar as informações. Chegou agora o momento de as interpretar.

Geraldo Peres provinha com certeza de uma família pertencente à oligarquia dos centros urbanos. O cunhado era almoxarife da Lousã e tinha um irmão escudeiro, o genro era mercador em Avô, o sobrinho provinha de Arganil e habitava numa freguesia de Tábua - o interior do distrito de Coimbra era certamente o local de origem da família. Muitas vezes se tem assinalado que o clero acolhia todos os que nele quisessem ingressar, homens da nobreza como gente do povo; assim se compreende que Geraldo Peres,

${ }^{75}$ Liber Anniversariorum Ecclesiae Cathedralis Colimbriensis (Livro das Kalendas), ed. crítica org. por Pierre David e Torquato de Sousa Soares, 2 vols., Coimbra, 1947$-1948$.

${ }^{76}$ V. Maria Helena da Cruz Coelho, Os homens ao longo do tempo e do espaço, in Nova História de Portugal dir. Joel Serrão e A. H. de Oliveira Marques, vol. III: Portugal em definição de fronteiras. Do Condado Portucalense à crise do século XIV, Lisboa. 1996, p. 180-181, onde analisa e comenta os resultados das investigações sobre a duração da vida humana na Idade Média realizadas por Eugénia Maria G. P. A. da Cunha, Paleobiologia das populações medievais portuguesas. Os casos de Fão e S. João de Almedina, Coimbra, 1994 (tese de doutoramento policopiada). V. também o que Bernard Guenée (o. c., p. 39-42) escreve sobre as idades dos quatro prelados medievais que estuda. 
sobrinho de um homem de origens por certo igualmente humildes mas que tinha chegado ao sólio episcopal ${ }^{77}$, pudesse seguir a carreira eclesiástica. Assim garantia uma forma de vida confortável, recebendo benefícios que lhe proporcionavam rendimentos consideráveis. Sobre a sua vocação, nada sabemos; mas ter recebido um benefício com cura de almas e nunca ter residido na igreja de que era prior não indicia especial zelo religioso. Não era o único: "a clericatura, para uma grande maioria, era um modo de

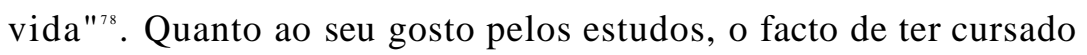
a Universidade não o prova cabalmente: o clero incentivava a aprendizagem do saber entre os seus membros, procurando melhorar a formação dos eclesiásticos. Por outro lado, não é de negar que a vontade de aprender podia ser um bom incentivo para o ingresso na vida clerical, dado que os proventos que esta proporcionava permitiriam o acesso à escola.

A imagem que os documentos transmitem de Geraldo Peres como eclesiástico parece encaixar perfeitamente no que sabemos sobre o clero de então. E é uma imagem que abrange um período temporal notável: como cónego da Sé, assistiu ao governo da diocese por sete prelados, e exerceu funções de relevo como vigário-geral de dois deles durante mais de dez anos. Sobreviveu à Peste Negra, conheceu a vida dura da segunda metade do século XIV, preocupou-se decerto com as guerras fernandinas e as que contra Castela se travaram na sequência da crise dinástica. No seu tempo eclodiu o Cisma do Ocidente, que dividiu a cristandade e se repercutiu na vida de então - na sua também por certo.

\footnotetext{
"Os prelados estudados por Bernard Guenée eram também homens cujo nascimento não explicava os lugares da hierarquia eclesiástica que vieram a ocupar (o. c., p. 20-22).

${ }^{78}$ Isaías da Rosa Pereira, o. c., p. 57.
} 
A vida religiosa não afastou Geraldo Peres da restante sociedade. Os laços familiares parecem ter sido importantes para ele: amparou a irmã, teve sobrinhos junto de si, chegou a ser tutor de um deles. Desobedecendo às normas canónicas, teve amores e filhos, que com carinho tratou, legitimando-os e tornando-os os seus principais herdeiros ${ }^{79}$. Em tudo isto, uma vez mais, o retrato traçado não colide com o que sabemos sobre a vida dos eclesiásticos do seu tempo.

Foi ainda um proprietário, de bens essencialmente rústicos, entre os quais avultavam, como seria de esperar nesta época, as vinhas. Não deixou, porém, de se interessar em possuir um forno, importante meio de produção que lhe permitia certamente ganhar bom dinheiro. Preocupou-se, como vimos, com a exploração do que era seu, seguindo, tanto quanto nos é dado conhecer, as práticas usuais na altura. Para acrescentar o património utilizou estratagemas que lhe permitissem contornar o escolho das leis desamortizadoras. Usou o seu poder sobre uma clientela que o rodeava para obter novos bens. Deixou-nos a impressão de um homem cioso dos seus haveres, que não hesitava em recorrer à justiça quando sentia ameaçados os direitos que lhe assistiam ${ }^{80}$, nem em ir ele próprio amanhar as suas terras quando havia o perigo de as perder.

Geraldo Peres, um cónego, um homem do seu tempo. Era nossa

${ }^{79} \mathrm{O}$ que, aliás, as constituições sinodais proibiam, bem como viverem juntos os clérigos e os seus filhos. Cf. Isaias da Rosa Pereira, o. $c$. As afirmações que fazemos reportam-se, naturalmente, a Fernão e Margarida Peres; com o terceiro filho não sabemos se houve tão grande proximidade.

${ }^{80}$ Assim o mostram os documentos que explorámos, c ainda um outro pelo qual sai vencedor de uma questão desconhecida e pede à parte vencida o pagamento das custas do processo, que atingem as 79 libras e 5 soldos (AUC, Móv.7, G.4, no 25, s.a. Agosto, 24, Coimbra). 
intenção, declarada no início deste trabalho, atingir o colectivo através de um caso individual. Esperamos tê-lo conseguido, sem no entanto esquecer a especificidade do destino humano que reconstituimos. Diz Bernard Guenée, na obra que temos vindo a citar, que "o estudo das estruturas faz compreender a história. $\mathrm{O}$ relato de uma vida faz senti-la" ${ }^{41}$. O sentir da história era um dos gostos, um dos dons do saudoso Professor Doutor Salvador Dias Arnaut. Neste trabalho fica a nossa homenagem à sua memória.

${ }^{81}$ O. c., p. 47. 


\section{DOCUMENTO $^{82}$}

1379 Maio, 21, Lousã - O tabelião da Lousã Geraldo Eanes lavra instrumento comprovativo de que Geraldo Peres é proprietário e explora os seus bens da Lousã.

A) A UC, Móv. 1, G.4, no 129 (pergaminho, estado razoável, gótica cursiva, sinal notarial).

Sabham quantos este stromento virem que na Era de mil e quatroçentos e dez e ssete annos vinte e huum dias de Maio indo eu Girald'Eanes tabeliom da Loussaa polia iffante dona Beetriz ssenhora dessa meesma per o caminho coinbrãao com Lourenço Anes meu filho a veer mhas erdades e vinhas que ei na dicta villa e termho delia parei mentes a ffundo do dicto caminho de mãao ssenestra e vi andar Girai Perez vigairo do bispo de Coinbra en hua sua erdade que chamom do Carvalho andando hi com el Martinho seu casseiro e Joham Andreu filho do Ssurdo lavrando com duas jugadas de bois e Gonçalo e Vaasqu'Eanes omees do dicto Girai Perez cavando anbos e dous e dicto Girai Perez ssemeando milho que tragia en huum ssaco. E eu dicto tabeliom veendo esto ffoi pera alo e ffalei com o dicto Girai Perez dizendo "Deus hos ssalve todos", dizendo o dicto vigairo e os outros todos "He ssejades vos vindo", tragendo o dicto Girai Perez en hua mãao o dicto saco com o dicto milho andando semendo o dicto milho polia dicta erdade e os ssobredictos lavrando e cavando como dicto he. $E$ logo per mim dicto tabeliom ffoi dicto contra o dicto Girai Perez "Que vos trouxe ora a esta terra? Gram tempo ha que vos aqui nom vim" e o dicto Girai Perez deu en resposta "Trouxe me esto que vos veedes e mingua de sservidores que nom posso aver por meus dinheiros bem louvado a Deus e a nos outros" e outras moitas palavras que fforam dietas

${ }^{82}$ Bem gostaríamos de incluir um apêndice com todos os documentos que dizem respeito directamente a Geraldo Peres. Na impossibilidade de o fazermos, porque o espaço de que dispomos é limitado, publicamos somente o mais interessante. Seguimos na transcrição as regras propostas por Avelino de Jesus da Costa, Normas gerais de transcrição e publicação de documentos e textos medievais e modernos, $3^{a}$ ed., Coimbra, 1993. 
antre as quaaes que o dicto Girai Perez assi disse contra mim dicto tabeliom. Disse "Bem ssabedes vos Girald'Eanes que bem ha huum ano e moito mais que eu possoio estou en posse desta erdade e que levei os ffructos e novos delia o que he notorio". Respondo eu dicto tabeliom e dixe que verdade era. Disse entom o dicto Girai Perez "Eu continuum a dicta posse como vos veedes e protesto de continuar daqui en deante assi como era e ante e depois e assi me daredes vos hum stromento ou dous e mais sse me mais comprirem". Dizendo eu que lhos daria e hindo me eu dicto tabeliom com o dicto meu ffilho contra as vinhas do Areal e fficando o dicto Girai Perez com sseus obreiros andar en sseu affan como dicto he. A cabo düa grande ora er parei mentes eu dicto tabeliom e vi andar o dicto Girai Perez no dicto logo do Areal hu chamam a Lagoa arendando com obreiros hüa ssa vinha que parte com outra vinha de Ffernam Gonçalvez e com caminho ${ }^{83}$ publico que vai pera a Lagoa dizendo eu contra o dicto Girai Perez "Gram trabalho e oge o vosso". Respondeu entom o dicto Girai Perez e disse "Ja vo llo dixe outra vez e esso medes vos digo", tomando aas vezes aixada e arrendava com os outros o dicto Girai Perez dizendo outra vez contra mim dicto tabeliom "Bem ssabedes vos Girald'Eanes que ha anno e moito mais que eu estou en posse desta vinha levando os ffrutos e novos delia o que he notorio", dizendo eu que verdade era. E logo o dicto Girai Perez disse "Eu continum a dicta posse como vos vedes e protesto de continuar tambem desta erdade e vinha come de todalas outras que eu ei en quaaesquer logares que ssejam daqui en deante assi come ora e dante e depois. E assi vos peço outro stromento que mhe ponhades junto com outro que vos ja pedi ou mho dedes todo en hum", fficando lhe eu dicto tabeliom por el. Testemonhas que pressentes fforam os ssobredictos lavradores e o dicto Lourenço Anes e Vaasco Dominguez alffaiate e Gonçallo Lourenço çapateiro moradores na dieta villa da Loussãa e o dicto Gonçallo e Vaasqu'Eanes e outros. E eu ssobredicto Girald'Eanes tabeliom da dieta villa da Loussãa polia dieta senhora iffante que com as dietas testemonhas a esto pressente foi e este stromento screvi e ffiz aqui meu sinal que tal (sinal) he.

Segue-se letra riscada. 


\section{Quadro I - PRESENÇAS DE GERALDO PERES EM REUNIÕES DO CABIDO}

\begin{tabular}{|c|c|}
\hline DATA & FONTE \\
\hline 1362 Nov. 16 & TT, Sé C. $.^{\text {a }} 2 .^{a}$ inc., M. 63, n. ${ }^{\circ} 2327$ \\
\hline 1363 Jan. 27 & Idem, M. 6, n. ${ }^{\circ} 310$ \\
\hline 1363 Jun. 5 & Idem, M. 74, n. $^{\circ} 2926$ \\
\hline 1365 Ag. 16 & Idem, M. 73, n. $^{\circ} 2846$ \\
\hline 1366 Ago. 24 & Idem, M. 78, n. $^{\circ} 3260$ \\
\hline 1367? Nov. 20 & Idem, M. 77, n. 3175 \\
\hline 1372 Fev. 20? & Idem, M. 75, n. ${ }^{\circ} 3042$ \\
\hline 1375 Jun. 20 & Idem, M. 50, n. ${ }^{\circ} 1998$ \\
\hline 1377 Dez. 21 & Idem, M. 82, n. ${ }^{\circ} 3740$ \\
\hline 1378 Mar. 26 & Idem, M. 75, n. $^{\circ} 3016$ \\
\hline 1378 Abr. 25 & Idem, M. 74, n. $^{\circ} 2950$, M. 76, n. $^{\circ} 3107$, M. 80, n. $^{\circ} 3471$ e 3523 \\
\hline 1378 Abr. 30 & Idem, M. 75, n. ${ }^{\circ} 2999$ \\
\hline 1378 Maio 12 & Idem, M.71,n. ${ }^{\circ} 267$ \\
\hline 1379 Jul. 29 & Idem,M. 74, n. $^{\circ} 2966$ \\
\hline 1380 Set. 5 & Idem, M. 5, n. ${ }^{\circ} 224$ \\
\hline 1383 Mar. 6 & Idem, M. 80, n. ${ }^{\circ} 3447$ \\
\hline 1386 Abr. 9 & Idem, M. 1, n. $^{\circ} 38$ \\
\hline 1388 Out. 26 & Idem. M. 76, n. ${ }^{\circ} 3097$ \\
\hline 1389 Jul. 24 & Idem, M.48, n..$^{\circ} 1911$ \\
\hline 1389 Set. 20 & Idem, M. 89, n. ${ }^{\circ} 4278$ \\
\hline 1391 Abr. 10 & Idem, M. 5, n. ${ }^{\circ} 233$ \\
\hline 1392 Mar. 1 & Idem, M. 72, n. ${ }^{\circ} 2833$ \\
\hline 1392 Nov. 6 & Idem, M. 2, n. ${ }^{\circ} 58$ \\
\hline 1394 Out. 12 & Idem,M. 5, n. 221 \\
\hline 1394 Out. 13 & Idem, M. 5, n. ${ }^{\circ} 287$ \\
\hline 1394 Out. 19 & Idem, M. 8,n. ${ }^{\circ} 417$ \\
\hline 1394 Dez. 16 & Idem, M. 75, n. $^{\circ} 3036$ \\
\hline 1395 Out. 4 & Idem, M. 70, n. ${ }^{\circ} 2618$ \\
\hline 1395 Nov. 10 & Idem. M. 75, n. ${ }^{\circ} 2993$ \\
\hline 1395 Nov. 19 & Idem, M. 81, n..$^{\circ} 3563$ \\
\hline 1397 Fev. 10 & Idem, M.3, n. ${ }^{\circ} 128$ \\
\hline
\end{tabular}




\section{Quadro no 2 - ACTUAÇÕES COMO VIGÁRIO-GERAL DO BISPO DE COIMBRA}

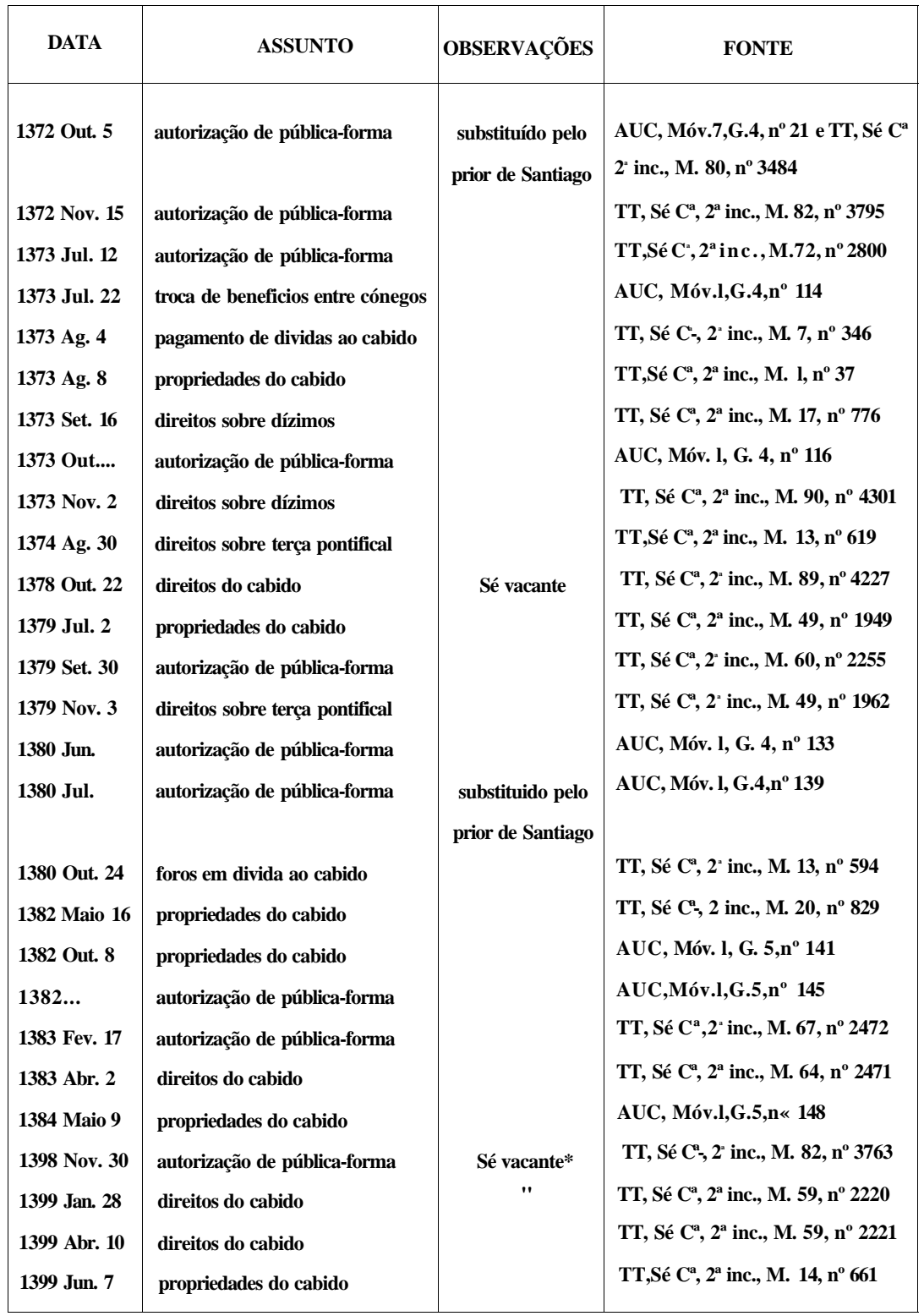

* E também vigário-geral o cónego da Sé Paio Martins. 


\section{Quadro no 3 - DOCUMENTOS RELATIVOS ÀS DÍVIDAS DE VASCO LOURENÇO}

\begin{tabular}{|c|c|}
\hline DATA E FONTE & SUMARIO \\
\hline $\begin{array}{l}1363 \text { Ag. 16, Lisboa } \\
\text { (AUC,Móv.l,G.3,nº 90) }\end{array}$ & $\begin{array}{l}\text { D. Pedro I passa carta de quitação a Vasco Lourenço relativamente ao cargo de almoxarife da } \\
\text { Lousã que exerceu entre } 1348 \text { Jun. } 24 \text { e } 1355 \text { Ag. 1, e à quinta de Fernão Lopes na Lousã de que } \\
\text { fora procurador entre } 1358 \text { Jun. } 24 \text { e } 1359 \text { Jun. } 24 \text {. }\end{array}$ \\
\hline $\begin{array}{l}1365 \text { Jan. 4, Lousã } \\
\text { (AUC, Móv.l, G.3, n 96) }\end{array}$ & Margarida Peres, viúva de Vasco Lourenço, pede uma pública-forma do doe. anterior. \\
\hline $\begin{array}{l}\text { 1366 Out. 20, Lousã-1367 } \\
\text { Mar. 25, Lousã } \\
\text { (AUC,Móv.l,G.3,nº100) }\end{array}$ & $\begin{array}{l}\text { Lopo Martins Taveira, sacador das dívidas del-rei na correição da Beira, lè um rol de que } \\
\text { constam duas dívidas de Vasco Lourenço, descobertas após ter sido passada a carta de quitação: } \\
331 \text { libras, } 13 \text { soldos, } 4 \text { dinheiros (de despesas na quinta de Fernão Lopes); } 233 \text { libras, } 3 \text { soldos, } \\
7 \text { dinheiros (da última arrecadação como almoxarife). } \\
\text { Nem a viúva nem o testamenteiro (o escudeiro Pero Lourenço) as pagaram ou têm dinheiro para } \\
\text { o fazer, pelo que os seus bens são postos a pregão de acordo com o que manda a lei. Sào arrematados } \\
\text { na segunda data por Afonso Anes de Celorico, por } 82 \text { libras, para pagar a segunda dívida. }\end{array}$ \\
\hline $\begin{array}{l}\text { 1366 Out. 20, Lousã-1367 } \\
\text { Mar. 25, Lousã } \\
\text { (AUC,Móv.l,G.3,n'101) }\end{array}$ & $\begin{array}{l}\text { O mesmo sacador, para pagar a primeira dívida, põe a pregão as casas de morada de Margarida } \\
\text { Peres, na Lousã, que o escudeiro Pero Lourenço arremata na segunda data por } 50 \text { libras. }\end{array}$ \\
\hline $\begin{array}{l}1368 \text { Jan. 3, Lousã } \\
\text { (AUC,Móv.l,G.3,nº101v.) }\end{array}$ & $\begin{array}{l}\text { Pero Lourenço, escudeiro, entrega as casas que arrematara a Afonso Anes. homem do cónego } \\
\text { Geraldo Peres (que é testemunha do acto), por } 50 \text { libras. }\end{array}$ \\
\hline $\begin{array}{l}1370 \text { Jul. 28, Lousã - } 1370 \text { Dez. } \\
\text { 1, Lousã- } 1371 \text { Fev. 2, Lousã } \\
\text { (AUC,Móv.l,G.3,nº } 106)\end{array}$ & $\begin{array}{l}\text { António Martins, sacador das dívidas del-rei na correição da Beira, lê um rol de que constam duas } \\
\text { dividas de Gil Gonçalves, almoxarife da Lousã entre Set. } 1345 \text { e Jan. 1348, e penhora os bens dos } \\
\text { herdeiros do seu fiador. São arrematados na segunda data por Vasco Domingues, procurador de } \\
\text { Maria Gomes, chaveira de Geraldo Peres. Nesse mesmo dia, o sacador mostra a Margarida Peres } \\
\text { as duas cláusulas de dívidas de Vasco Lourenço (a segunda já só no montante de } 116 \text { libras e } 13 \\
\text { soldos). Ela diz-lhe que já pagou, mas as provas estão em Coimbra com seu irmão Geraldo Peres, } \\
\text { pelo que pede tempo para as apresentar. Não obstante, o sacador põe a pregão os bens que ela e } \\
\text { Pero Lourenço trazem. Na terceira data, esses bens sào arrematados por } 130 \text { libras por Vasco } \\
\text { Lourenço, homem do cónego Geraldo Peres (que parece ter testemunhado o acto). }\end{array}$ \\
\hline $\begin{array}{l}1370 \text { Set. 28, Coimbra } \\
\text { (AUC, Móv.l,G.3, }{ }^{\circ} 108 \text { ) }\end{array}$ & $\begin{array}{l}\text { Mostra-se ao escrivão do rei no almoxarifado de Coimbra um livro de } 1366 \text { com duas cláusulas } \\
\text { de pagamentos para cobrir as dívidas do almoxarife da Lousã Vasco Lourenço. Sào } 50 \text { libras } \\
\text { (provenientes da compra das casas por Pero Lourenço) e } 66 \text { libras, 13,5 soldos e mealha } \\
\text { (provenientes das arrematações de Afonso Anes de Celorico e de Maria Gomes). }\end{array}$ \\
\hline $\begin{array}{l}1391 \text { Jul. 3, Coimbra } \\
\text { (AUC,Móv.l,G.5,n'161) }\end{array}$ & $\begin{array}{l}\text { Perante o juiz de Coimbra, comparecem Geraldo Peres e o sacador das dividas del-rei Afonso } \\
\text { Martins. O cónego declara que a irmã já tinha saldado as dívidas de Vasco Lourenço e mostra os } \\
\text { documentos comprovativos, que sào copiados. }\end{array}$ \\
\hline
\end{tabular}


Quadro no 4 -A "CLIENTELA" DE GERALDO PERES

\begin{tabular}{|c|c|c|c|c|}
\hline NOME & IDENTIFICAÇÃO & FUNÇÃO & DATA & FONTE \\
\hline Afonso Anes & $\begin{array}{l}\text { familiar de G.P. } \\
\text { homem de G.P. }\end{array}$ & $\begin{array}{l}\text { testemunha } \\
\text { compra bens } \\
\text { testemunha } \\
\text { compra bens } \\
\text { testemunha }\end{array}$ & $\begin{array}{l}1367 \text { Set. 27. Coimbra } \\
1368 \text { Jan. 2, Lousã } \\
1368 \text { Jan. 3, Lousã } \\
1373 \text { Jul. 22, Coimbra } \\
1379 \text { Fev. 2. Coimbra } \\
1380 \text { Jun. 27, Coimbra }\end{array}$ & $\begin{array}{l}\text { AUC,Móv.l,G.3,nº58 } \\
\text { AUC,Cofre,Col.pergs.extr. } \\
\text { AUC,Móv.l,G3.n¹01v } \\
\text { AUC,Móv.l,G.4,n¹15 } \\
\text { AUC,Móv.l,G.4,nº'128 } \\
\text { AUC,Móv.l,G.4,nºl36 }\end{array}$ \\
\hline Afonso Esteves & homem de G.P. & testemunha & 1378 Dez. 14, Lousã & AUC,Móv.l.G.4,nº127 \\
\hline Afonso Martins & bacharel, criado de G.P. & testemunha & 1396 Ag. 25, Coimbra & $\begin{array}{l}\text { TT.Sé } C^{a} \text { inc.,M.54,no } \\
2098\end{array}$ \\
\hline Aires & azemel de G.P. & testemunha & 1378 Out. 2, Lousã & AUC,Móv.l,G.4.n¹27 \\
\hline Gonçalo Anes & homem de G.P. & $\begin{array}{l}\text { testemunha } \\
\text { cava terras de G.P. }\end{array}$ & $\begin{array}{l}1378 \text { Dez. 14, Lousã } \\
1379 \text { Maio, 21, Lousã }\end{array}$ & $\begin{array}{l}\text { AUC,Móv.I,G.4,nº } 127 \\
\text { AUC,Móv.I,G.4,n'129 }\end{array}$ \\
\hline João Andreu & filho do Surdo & lavra terras de G.P. & 1379 Maio, 21, Lousã & AUC,Móv.I,G.4.n'129 \\
\hline João Mouro & homem de G.P. & testemunha & 1378 Dez. 14, Lousã & AUC,Móv.l,G.4,nº127 \\
\hline João Vicente & homem de G.P. & testemunha & 1380 Jun. 27, Coimbra & AUC,Móv.l,G.4,nº136 \\
\hline Lourenço Domingues & homem de G.P. & testemunha & 1370 Set. 11, Coimbra & AUC,Móv.7,G.4,nº19 \\
\hline Lourenço Fernandes & homem de G.P & testemunha & 1378 Dez. 14, Lousã & AUC,Móv.I,G.4.n'127 \\
\hline Maria Gomes & $\begin{array}{l}\text { nat. mor. Coimbra } \\
\text { servidora de G.P. (man- } \\
\text { ceba, segundo traslado } \\
\text { de } 1391 \text { ) } \\
\text { chaveira de G.P. } \\
\text { nat. mor. Coimbra }\end{array}$ & $\begin{array}{l}\text { compra bens } \\
\text { paga ao almoxarife de } \\
\text { Coimbra através de } \\
\text { Afonso Anes, procura- } \\
\text { dor compra bens através } \\
\text { do procurador Vasco } \\
\text { Domingues, alfaiate } \\
\text { troca bens com G.P. }\end{array}$ & $\begin{array}{l}1370 \text { Set. 11, Coimbra } \\
1370 \text { Set. 28, Coimbra } \\
\text { (traslado de } 1391 \text { Ag. } 1 . \\
\text { Coimbra) } \\
1370 \text { Dez. 1, Lousã } \\
1371 \text { Fev. 5, Coimbra }\end{array}$ & 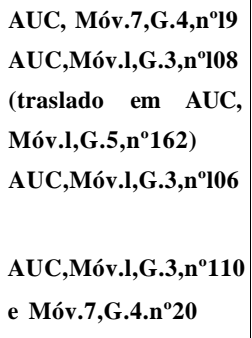 \\
\hline Martim Vasques & homem de G.P. & testemunha & 1368 Jan. 3, Lousã & AUC,Móv.I.G.3,n'101v \\
\hline Martinho & caseiro de G.P. & lavra terras de G.P. & 1379 Maio 21, Lousã & AUC,Móv.l.G.4.n¹29 \\
\hline
\end{tabular}




\begin{tabular}{|c|c|c|c|c|}
\hline NOME & IDENTIFICAÇÃO & FUNÇÃO & DATA & FONTE \\
\hline Vasco Lourenço & $\begin{array}{l}\text { homem de G.P. } \\
\text { familiar de G.P. }\end{array}$ & $\begin{array}{l}\text { testemunha } \\
\text { compra bens } \\
\text { testemunha }\end{array}$ & $\begin{array}{l}1370 \text { Set. 28, Coimbra } \\
1371 \text { Fev. 2, Lousã } \\
1371 \text { Fev. 5, Coimbra } \\
1373 \text { Jul. 22, Coimbra }\end{array}$ & 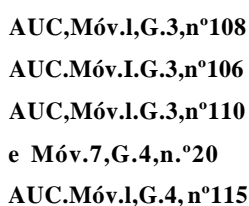 \\
\hline
\end{tabular}

\section{Quadro no 5 - PROCURADORES DE GERALDO PERES}

\begin{tabular}{|c|c|c|c|}
\hline NOME & IDENTIFICAÇÃO & EM SEU NOME & DATA E FONTE \\
\hline Afonso Anes & $\begin{array}{l}\text { medidor do celeiro do cabido da } \\
\text { Sé de Coimbra }\end{array}$ & toma posse da vinha do Almegue & $\begin{array}{l}1394 \text { Abr. 20, Almegue } \\
\text { (AUC, Móv.l,G.5, n 162) }\end{array}$ \\
\hline Gil Peres * & clérigo, mor. Lousã & $\begin{array}{l}\text { recebe procuração } \\
\text { toma posse dos bens que Geraldo } \\
\text { Peres possuía na Lousã e no seu } \\
\text { termo }\end{array}$ & $\begin{array}{l}1397 \text { Abr. 13, Coimbra } \\
1397 \text { Abr. 27, Urzidel } \\
\text { (AUC,Móv.1,G.6,nº 174) }\end{array}$ \\
\hline Gonçalo Martins & prior de Macieira & $\begin{array}{l}\text { toma posse do priorado da igreja } \\
\text { de S. Miguel de Aveiro }\end{array}$ & $\begin{array}{l}1352 \text { Jul. 10, Aveiro } \\
\text { (Milen.Aveiro, doc. no 67) }\end{array}$ \\
\hline João Anes de Soure & & $\begin{array}{l}\text { reclama perante o ouvidor de } \\
\text { Coimbra as custas de um pro- } \\
\text { cesso em que Geraldo Peres é } \\
\text { vencedor }\end{array}$ & $\begin{array}{l}\text { s.a. Ag. 24, Coimbra } \\
\text { (AUC, Móv.7,G.4,nº 25) }\end{array}$ \\
\hline
\end{tabular}

* Representa o cónego, sem explicitamente se dizer que é o seu procurador, numa demanda de 1390 Dez. 17, Lousã (AUC, Móv.l, G.5, n 160, e G.7, n 180). 
Quadro n 6 - CARTAS DE QUITAÇÃO A GERALDO PERES

\begin{tabular}{|c|c|c|c|c|c|}
\hline DATA E FONTE & PREBENDEIRO & $\begin{array}{l}\text { PAGAMENTO } \\
\text { EFECTUADO }\end{array}$ & REFERENTE A & $\begin{array}{l}\text { DATA A QUE SE } \\
\text { REFERE }\end{array}$ & OBSERVAÇÕES \\
\hline $\begin{array}{l}1368 \text { Fev. 17, Coimbra } \\
\text { (AUC,Móv.l,G.3,n'103) }\end{array}$ & Afonso Martins... & 34.5 libras & & $\begin{array}{l}\text { tempo em que foi } \\
\text { prebendeiro da Sé }\end{array}$ & $\begin{array}{l}\text { dinheiro pago através } \\
\text { de Lourenço Vasques, } \\
\text { cónego e prior de } \\
\text { Miranda }\end{array}$ \\
\hline $\begin{array}{l}\text { 1371 Jan. 7, Coimbra } \\
\text { (AUC,Móv.l,G.3,n'109) }\end{array}$ & $\begin{array}{l}\text { Afonso Domingues } \\
\text { de Aveiro }\end{array}$ & - & $\begin{array}{l}\text { pensões das casas, } \\
\text { herdades e outros } \\
\text { bens que traz }\end{array}$ & $\begin{array}{l}\text { tempo em que foi } \\
\text { prebendeiro da Se. } \\
\text { até } 1370 \text { Jun. } 24\end{array}$ & - \\
\hline $\begin{array}{l}\text { 1382 Jun. 12. Coimbra } \\
\text { (AUC.Móv.7,G.4.n³0) }\end{array}$ & $\begin{array}{l}\text { Afonso Domingues } \\
\text { de Aveiro }\end{array}$ & & $\begin{array}{l}\text { pensões dos empra- } \\
\text { zamentos que traz } \\
\text { (casas em que mo- } \\
\text { ra, olivais e quinta } \\
\text { do Beiçudo); di- } \\
\text { nheiro da compra de } \\
\text { panos de cor e de } \\
\text { outras dividas }\end{array}$ & $\begin{array}{l}\text { tempo em que foi } \\
\text { prebendeiro da Sé }\end{array}$ & \\
\hline $\begin{array}{l}\text { 1382 Jun. 16. Coimbra } \\
\text { (AUC, Móv.l.G.5. no 140) }\end{array}$ & $\begin{array}{l}\text { Afonso Domingues } \\
\text { de Aveiro }\end{array}$ & & $\begin{array}{l}\text { pensões dos empra- } \\
\text { zamentos que traz: } \\
\text { dinheiro da compra } \\
\text { de panos de cor e de } \\
\text { outras dividas }\end{array}$ & $\begin{array}{l}\text { tempo em que foi } \\
\text { prebendeiro da Sé, } \\
\text { até } 1381 \text { Jun. } 24\end{array}$ & \\
\hline $\begin{array}{l}\text { 1390. Janeiro, 14, Coimbra } \\
\text { (AUC,Móv.l,G.5,n } \text { n }^{\circ} \text { 159) }\end{array}$ & $\begin{array}{l}\text { pai de Afonso Mar- } \\
\text { tins... }\end{array}$ & & $\begin{array}{l}\text { pensões dos prazos } \\
\text { que traz (olivais, } \\
\text { casas de morada, } \\
\text { quinta de Traveira } \\
\text { de Beiçudo e casais } \\
\text { de Bruscos que fo- } \\
\text { ram de Vasco } \\
\text { Afonso): dinheiro } \\
\text { da compra de panos } \\
\text { de cor e de outras } \\
\text { dívidas }\end{array}$ & $\begin{array}{l}\text { tempo em que o pai } \\
\text { foi prebendeiro da } \\
\text { Sé e recebedor das } \\
\text { dízimas do cabido }\end{array}$ & $\begin{array}{l}\text { Geraldo Peres reco- } \\
\text { nhece ter recebido } \\
\text { todos os dinheiros da } \\
\text { sua prebenda durante } \\
\text { esse tempo }\end{array}$ \\
\hline
\end{tabular}




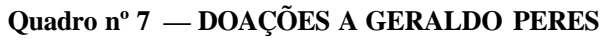

\begin{tabular}{|c|c|c|c|}
\hline DATA E FONTE & DOADORES & MOTIVOS & BENS DOADOS \\
\hline $\begin{array}{l}\text { 1368 Jan, } 2 \text { Lax̃̃ } \\
\text { (AUC, Cofre, Col. pergs. extr.) }\end{array}$ & Maggnda Peres, imã de Geraldo Peres & ser seu imão e receber dele grande ajuda & $\begin{array}{l}\text { todos os bens que possui em Coinbra e em qualquer outr } \\
\text { lugar }\end{array}$ \\
\hline $\begin{array}{l}1378 \text { Out. } 2 \text { Laxã } \\
\text { (AUC,Móv.l,G.4,nºn'27)* }\end{array}$ & Lourenço Anes, cérigo raçoeino de Santa Mara de Góis & muito bem recebido & $\begin{array}{l}\text { figueiras situadas dentro do cortinhal de Geraldo Peres, na. } \\
\text { Louxã }\end{array}$ \\
\hline $\begin{array}{l}1379 \text { Ahr. 25, Loux̃̃ } \\
\text { (AUC, Móv.l, G.4, n 127) }\end{array}$ & $\begin{array}{l}\text { Vasco Domingues, alfaiate e besteiro do conto, e mulher Inês } \\
\text { Eanes, moradores na Lax̃̃ }\end{array}$ & $\begin{array}{l}\text { bem. ajuda, defendimento. mantimentos e outros bens } \\
\text { recebidos por eles e pelo immão. Lourenço Domingues }\end{array}$ & $\begin{array}{l}4 \text { vinhas, } 2 \text { herdades, } 1 \text { casa, parte de cortinhal, no tmo } \\
\text { da Lous̃a, adquiridos entre } 1377 \text { e } 1379 \text { por } 261 \text { libras }\end{array}$ \\
\hline $\begin{array}{l}1388 \text { Nov. 3, Coimbra (casas de Geraldo Peres) } \\
\text { (AUC.Móv.l,G.5,n'155) }\end{array}$ & $\begin{array}{l}\text { Afonso Martins Galego e mulher Marganida Peres, moradores } \\
\text { ea Cemache }\end{array}$ & $\begin{array}{l}\text { serem velhos, cansados e "agravados de muitas outras doores" } \\
\text { e demasiado pobres para aproveitar os seus bens; bem e ajuda } \\
\text { recebidos }\end{array}$ & $\begin{array}{l}\text { bens em Cemadhe (oom condição de Geraldo Peres pagar } \\
\text { os direitos aos senhorios) }\end{array}$ \\
\hline $\begin{array}{l}1391 \text { Ag. 1, Coimbra } \\
\text { |AUC.Móv.l,G.6,n'162) }\end{array}$ & Estêvão Anes e mulher Alta Domingues, moradores em Pencta & $\begin{array}{l}\text { boas obras e ajuda recebidas em feitos e demandas tidos } \\
\text { perante os juizes de Coimbra e Penela e o bispo de Coimbra } \\
\text { seus vigários, e muitos consellos de direito (avaliam as suas } \\
\text { boas obras em } 500 \text { libras) }\end{array}$ & $\begin{array}{l}1 \text { courda de vinha babrusca, om árvores e pertenças, no } \\
\text { e lugar de Don 'Andru, termo da Lox̃̃ }\end{array}$ \\
\hline $\begin{array}{l}1395 \text { Fev. 9, Louxã (pousadas de Geraldo Peres) } \\
\text { AUC,Móv.l,G.4,n¹38) }\end{array}$ & $\begin{array}{l}\text { Marim, sapateiro, e muhrer Mangaida Domingues, moradores } \\
\text { na Lous̃̃ }\end{array}$ & $\begin{array}{l}\text { mita ajuda, bem fazer e defendimento recebidos, e o facto } \\
\text { de morarm em herdade do cónego }\end{array}$ & $\begin{array}{l}\text { casa com fomo e direitos na Lak̀̀ (compraramma em } 138 \\
\text { e } 1382 \text { e doaramma logo a Geraldo Peres, renowam agora } \\
\text { a doação por ele ter perdido o documento comprovativo) }\end{array}$ \\
\hline
\end{tabular}

* Esta doação surge incluída entre os documentos comprovativos da aquisição dos bens da doação que se segue, de 1379 Abril, 25 , em que não considerámos estes bens. 
Quadro $n^{\circ} 8$-COMPRAS FEITAS POR DEPENDENTES DE GERALDO PERES

\begin{tabular}{|c|c|c|c|c|}
\hline DATA E FONTE & COMPRADOR & BENS COMPRADOS & PREÇO & OBSERVAÇÕES \\
\hline $\begin{array}{l}\text { 1368 Jan 3. Loũ̃ } \\
\text { (AUC, Móvl. G.3,ñ101v) }\end{array}$ & Afonso Anes, homem de Geraldo Peres & casas em que morava Magaida Peres, na Louśn & $\begin{array}{l}50 \text { libras } \\
\text { (preço de arrematação) }\end{array}$ & Geraldo Peres testemunha o acto \\
\hline $\begin{array}{l}1370 \text { Set. 11. Coimbra (casa de Geraldo Peres) } \\
\text { (AUC,Móv.7,G.4,n¹9) }\end{array}$ & Màa Gomes, natural e moradora em Coimbra & $\begin{array}{l}\text { herdade da Encruvilhada, herdade à Papanata } \\
\text { vinha do Pinheiro no Areal (termo da Lousã) }\end{array}$ & $\begin{array}{l}100 \text { libras } \\
\text { (pagas em } 250 \text { gentis brancos de } 8 \text { soldos cada) }\end{array}$ & constam do anukamento de bens de 1397 \\
\hline $\begin{array}{l}1370 \text { Dez 1. Louxã } \\
\text { (AUC.Móv.l.GJ.n'106) }\end{array}$ & $\begin{array}{l}\text { Maia Gomes chaveira de Geraldo Peres } \\
\text { (através do seu procurador Vasoo Domingues, } \\
\text { alfaiate da Lousã) }\end{array}$ & $\begin{array}{l}\text { vinhas, herdades e cortes em Urzidel. temo da } \\
\text { Lousã }\end{array}$ & $\begin{array}{l}334 \text { libras } \\
\text { (preço de arrematação) }\end{array}$ & $\begin{array}{l}\text { Geraldo Peres parece ter testemunhado este } \\
\text { acto; os bens constam do anmamento de } 1397\end{array}$ \\
\hline $\begin{array}{l}1371 \text { Fev. } 2 \text { Louxã } \\
\text { (AUC. Móvl. G3, no no 106) }\end{array}$ & Vasco Lourença, homem de Geraldo Peres & $\begin{array}{l}\text { bens penhorados a Margarida Peres e Pero } \\
\text { Lourengo }\end{array}$ & $\begin{array}{l}130 \text { libras } \\
\text { (preģo de anrematação) }\end{array}$ & Geraldo Peres parece ter testemmbado este acto \\
\hline $\begin{array}{l}1379 \text { Fev. 2, Cimbra } \\
\text { (AUC.Móv.l,G.4,nº'128) }\end{array}$ & Afonso Anes. homem de Geraldo Peres & uma casa na Louxã & 15 libras & a casa confionta com casas de Geraldo Peres \\
\hline
\end{tabular}




\section{Quadro $n^{\circ} 9$ - ROL DE PROPRIEDADES DE GERALDO PERES}

NA LOUSÃ EM 1397 (AUC, Móv.l, G.6, n¹74)

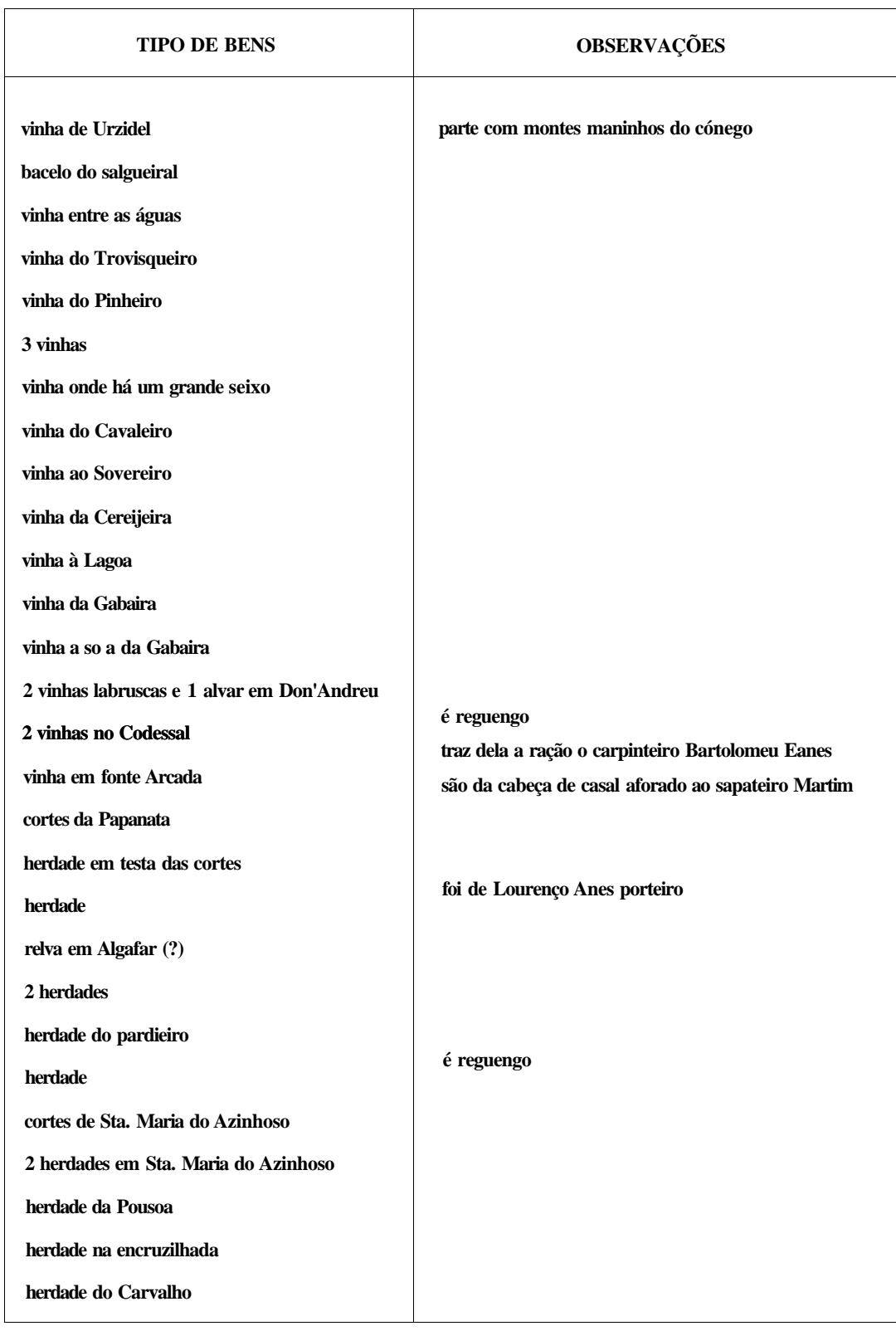




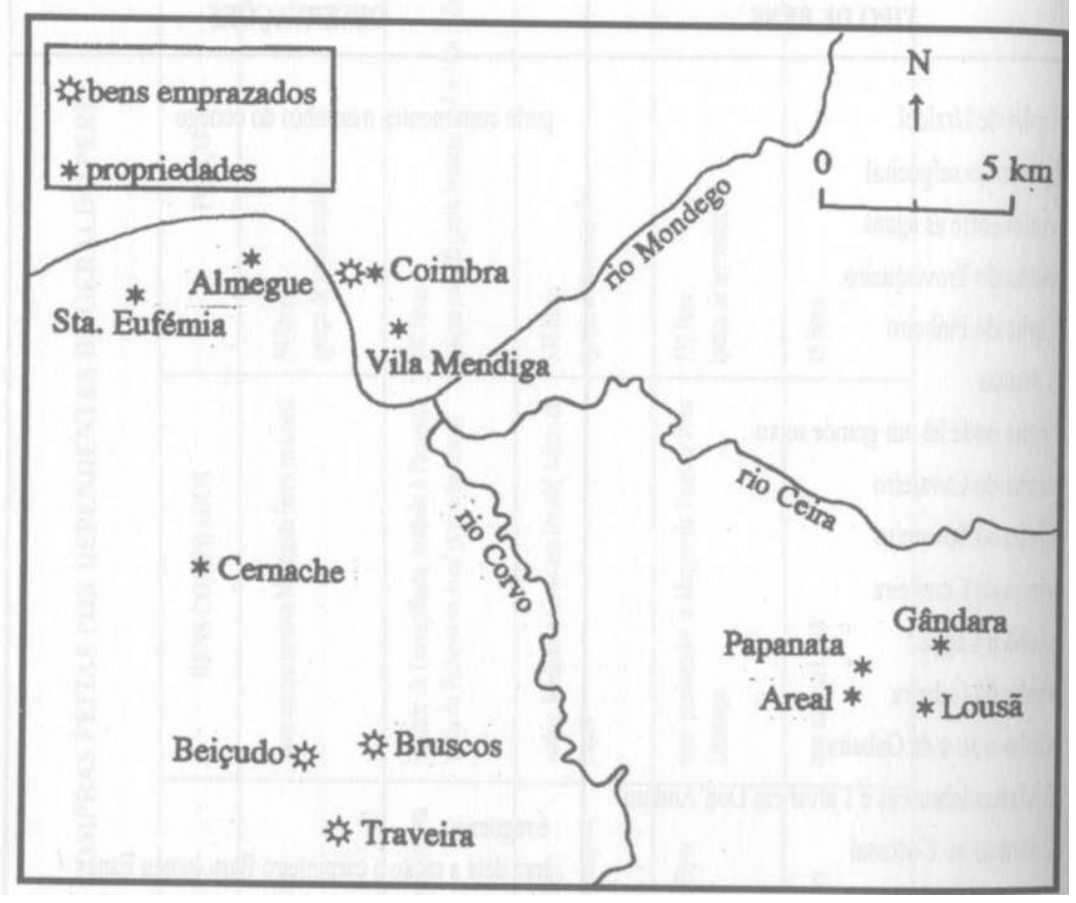

Mapa n. ${ }^{\circ} 1$ - LOCALIZAÇÃo DO PATRIMÓNIO DE GERALdO PERES 